\title{
Lean Philosophy for Global Competitiveness in Ethiopia Chemical Industries: Review
}

Kassu Jilcha* and Daniel Kitaw

School of Mechanical and Industrial Engineering, Addis Ababa Institute of Technology, Addis Ababa University, Ethiopia

\begin{abstract}
This study attempts to investigate the global competitiveness scenario in chemical manufacturing industries in line with lean thinking. The objective of this article is also to understand the concept of lean manufacturing, its philosophy, various tools and techniques, lean implementation benefits and barrier towards lean implementation of chemical industries in Ethiopia. Competitiveness of chemical manufacturing industry is not easily attainable since chemical products nature is variant. There are challenges which hinder the development of chemical industries production. The chemical industries contribution to the economy is very small when compared to agriculture contribution due to infant stage of the industrial group in general. The methods that can bring the chemical industries development and increase competitiveness is one lean thinking revolution. The big challenges noticed in this study found are chemical manufacturing industries have not diffused lean thinking into their process. The chemical industries consume more energy and resources with high technology. As a result of these, the development of chemical manufacturing industry in Ethiopia is darting and at initial stage in contributing for the country economics in employment, GDP, and self-sustained economy. Lean philosophy utilization to companies needs more commitment by the industrial sectors worker and kaizen institute.
\end{abstract}

Keywords: Competitiveness; Lean chemical; Chemical; Manufacturing industries; Challenges

\section{Introduction}

Global competitiveness achievement cannot be predicted only with establishment of manufacturing industries. Global competitiveness is the existence of competition among diverse organizations that serve global customers. An index of the competitiveness of the countries in the world is compiled every year by the World Economic Forum/ WEF. The International Institute for Management Development/ IIMD/ defines competitiveness as "a field of economic knowledge which analyzes the facts and policies that shaped the ability of a nation to create and maintain an environment that sustains more value creation for its enterprises and more prosperity for its people." WEF definition is: "the ability of a country to achieve sustained high rates of growth in gross domestic product (GDP) per capita." Therefore, only nations with high levels of productivity will become domestically and globally competitive and have the capacity to exploit existing market opportunities to sustain and expand employment and real income growth in the long term.

Any organization that wants to successfully compete in the marketplace must focus on customer requirements. These requirements can be numerous even for a narrow customer segment. An organization must translate customer requirements into objectives for operations known as competitive priorities. Examples of competitive priorities include low cost, consistent quality, and on-time delivery [1].

Global competition, uncertain demand environment and higher consumer expectations are among many drivers for companies to adopt lean manufacturing principles and tools. Lean principle can be characterized in short by "doing more with less". This lean philosophy focuses on the elimination of waste and excess from the tactical product flows and represents an improvement and sometimes an alternative model to that of capital-intensive mass production with its large batch sizes, dedicated assets and hidden wastes. Lean manufacturing offers a wide set of lean mechanisms and tools to achieve these goals [2]. The global industry in $21^{\text {st }}$ century has forced most of the leaders in several sectors to implement more competitive manufacturing system. The best answer as found in most of the journals is lean manufacturing. Lean manufacturing helps in enhancing production processes and boosting up the employees job satisfaction [3].

Lean manufacturing will be the standard manufacturing mode of the $21^{\text {st }}$ century [4]. There is no alternative to lean manufacturing [5]. Researchers agreed that lean manufacturing could be a cost reduction mechanism and if well implemented it will be a guideline to be world class organization [6]. Lean manufacturing by now is a widely discussed and applied manufacturing philosophy, in a variety of industries across the globe. The fundamental concept of lean manufacturing is to provide a quality product while also ensuring that the product does not cost too much to the customer [7].

Lean strategies make enterprises competitive and profitable in the global economy by cost reduction, which can be realized by reducing manufacturing costs. The ultimate goal of lean manufacturing systems is to realize a balanced and smooth flow of production. Key benefits of the lean system are reduced inventory levels, high quality, reduced lead times, increased productivity and equipment utilization, and reduced amounts of scrap and rework [8]. These benefits, in turn, lead to cost

${ }^{*}$ Corresponding author: Kassu Jilcha, School of Mechanical and Industrial Engineering, Addis Ababa Institute of Technology, Addis Ababa University, Ethiopia, Tel: +25191301774; E-mail: jkassu@gmail.com

Received September 29, 2015; Accepted October 13, 2015; Published October 17,2015

Citation: Jilcha K, Kitaw D (2015) Lean Philosophy for Global Competitiveness in Ethiopia Chemical Industries: Review. J Comput Sci Syst Biol 8: 304-321. doi: $10.4172 / j c s b .1000205$

Copyright: ( 2015 Jilcha K, et al. This is an open-access article distributed under the terms of the Creative Commons Attribution License, which permits unrestricted use, distribution, and reproduction in any medium, provided the original author and source are credited. 
reduction. The basis of competition, which used to be the product's price, switched to availability of products and products quality that satisfy customer. The agile manufacturing system proved to be efficient in such competition by enabling manufacturing enterprises to cope with delivering varieties of products and with fluctuating demand [9].

The chemical industry is an indispensable and integral constituent of the growing Global industry. The mankind is immensely benefited, right from its inception till date, by the use of chemicals and life, without chemicals, is unimaginable and inconceivable. The wide range of chemical products play vital role in catalyzing not only the economy of the World, but also making the life-style of human beings comfortable and sophisticated. Chemical industry sector is accepted to cover a wide range of processes which undergo reaction of individual components to give a specific product. The definition of the sector varies from country to country depending on the industrialization level as well as the direction of economic growth of the country. Mostly it is agreed that definitions adopted for statistical economic purposes vary from country to country, but in all cases it is believed that the chemical sector covers a wide range of industries.

Global competitiveness of chemical industries product is the advantage of the companies to compete equivalently of more than their competitors by the products or services rendered to the customer with value added scenario or meeting needs of customer expectation or exceeding [10]. This is true for chemical manufacturing and process industries.

Lean's application in discrete manufacturing is well known. It even has won a role in non-manufacturing industries such as healthcare. However, most people in the chemical industry haven't seriously considered lean's strategic advantages for the processes right around them. Many chemical companies dismiss lean as a low-level improvement activity because they don't appreciate its power and value. We must make the case for Lean more clearly and broadly. The chemical industry competitiveness in the global scenario with the implementation of lean manufacturing principle is mandatory. The industrial development with competitive advantage is not spoken without increased productivity and decreased wastes of manufacturing processes [11]. Here, this is what lean is doing.

Ethiopia is also striving for competition in the industrial development and industrial production economic contribution. Since in the developed countries many chemical industries has not consider the lean application, Ethiopian chemical manufacturing industries has no lean thinking application specifically but practicing some tools intentionally in their industries even though the chemical industries development is almost none in GDP contribution in the country. Ethiopia has strategic plan for the development of chemical industries especially in the production of chemical and chemical related products production. This study has addressed the competitiveness of Ethiopian chemical industries considering the main chemical industrial groups.

This research has been structured as follows in sections: Section 4 methodology part, Section 5 literature review, Section 6 chemical industries competitiveness, Section 9 ways forward and last section is conclusion.

\section{Methodology}

This study was conducted based on the data obtained from different sources. The data obtained from secondary such as international chemical councils, Ethiopian ministry of industry, chemical and construction material industry development institute, Ethiopian Kaizen
Institute, case manufacturing documents. The other related literature reviews were conducted intensively to see at the lean principles and it application in chemical or related process industries. Some data collection technique used was through case company environment visits and working area observation in line with interviews. The other interview was also made with the chemical industry development management. The detail discussions have been conducted in subsequent section.

\section{Literature Review}

Literature part explains entirely the global competitiveness clear definition and touches the lean manufacturing historical conditions. It also sees the key benefit of lean and its tools, lean chemical management and applications, the way of driving out the chemical wastes, lean comparison with other improvement tools and finally discus about the gaps existed in many researches about lean manufacturing.

\section{Global competitiveness}

Competitiveness is defined as how effectively an organization meets the wants and needs of customers relative to others that offer similar goods or services. Competitive strategy is defined as the strategy which looks for a preferably competitive situation for the organization in which it acts. Competitive strategy aims to establish certain levels of profits and sustain that in a competitive atmosphere of industry [12].

\section{Background of lean manufacturing}

Lean was founded in post-WWII Japan in 1940 by Sakichi Toyoda and chief engineer Taiichi Ohno, Toyota Production System (TPS) is largely grounded in the systematic elimination of what Toyota identified as the eight deadly wastes. He had started work on the Toyota Production system and continued its development into the late 1980s unhindered by the advancements in computers which had allowed mass production to be further 'Enhanced' by material requirement planning (MRP) Systems. By the 1970s Toyota's own supply base was 'lean'; by the 1980s their distribution base was also 'lean. The following Table 1 compares the two types of production (mass and lean) production. Mass production philosophies originally developed by Henry Ford, i.e., large high volume production of standardized products with minimal product changeovers [13]. The Machine that Changed the World [14] compared and contrasted the Mass Production System seen in the US and Europe, with the Lean Production System, seen in Japan, within the automotive industry. Table 1 is a summary of some of the comparisons highlighted by Womack et al. Table 1 compares the traditional production system and lean production.

\begin{tabular}{|c|c|c|}
\hline & Mass production & Lean production \\
\hline Basis & Hennery Ford & Toyota \\
\hline People-design & $\begin{array}{l}\text { Narrowly skilled } \\
\text { professionals }\end{array}$ & $\begin{array}{l}\text { Team of multi-skilled workers at } \\
\text { all levels in the organizations }\end{array}$ \\
\hline People -production & $\begin{array}{l}\text { Unskilled or semi-skilled } \\
\text { workers }\end{array}$ & $\begin{array}{l}\text { Team of multi-skilled workers at } \\
\text { all levels in the organizations }\end{array}$ \\
\hline Equipment & $\begin{array}{l}\text { Experts, single purpose } \\
\text { machines }\end{array}$ & $\begin{array}{c}\text { Manual and automatized } \\
\text { systems which can produce } \\
\text { large volume with large product } \\
\text { variety }\end{array}$ \\
\hline $\begin{array}{l}\text { Production } \\
\text { methods }\end{array}$ & $\begin{array}{l}\text { Makes high volume of } \\
\text { standardized products }\end{array}$ & $\begin{array}{l}\text { Make the product which the } \\
\text { customers ordered }\end{array}$ \\
\hline $\begin{array}{l}\text { Organizational } \\
\text { philosophy }\end{array}$ & $\begin{array}{l}\text { Hierarchical- } \\
\text { management take } \\
\text { responsibility }\end{array}$ & $\begin{array}{l}\text { Value streams using appropriate } \\
\text { levels of empowerment- } \\
\text { pushing responsibility further } \\
\text { down the organization }\end{array}$ \\
\hline Philosophy & Aim for good enough & Aim for perfection \\
\hline
\end{tabular}


In comparison, the term 'lean' comes from the 'upside' of the production method which requires 'half the human effort, half the manufacturing space, half the investment and half the engineering hours to develop a new product in half the time'[13].

TPS uses several different tools to strategically align not only their production facilities but their supplier's facilities in the elimination process of these eight wastes [15] as seen in Table 2. The definition of lean, its principles and main concepts, come under lean philosophy. Lean is defined as a process that includes five steps: the first step is defining customer value, then defining value stream, making it 'flow', establish pull, and the last step is striving for excellence [16].

The core idea behind lean is minimizing waste, therefore creating more value for customers with fewer resources. A company can reduce costs and keep prices low without adversely affecting profits or quality by controlling the amount of waste generated during production. Estimates suggest that on an average $95 \%$ of manufacturing activities fall either under non-value adding time or non-value adding cost $[13,15,16]$

Lean value chain $[10,14,17]$ : lean manufacturing, Total quality management, IT-Solutions, Virtual integration, Lean supply chain, Outsourcing, Just in Time and flexible manufacturing are the basic lean value chain.

Lean philosophy is emphasizing on total system, Lean principles is focusing the flow of production material throughout the entire enterprise and Lean practices are supporting lean principles by reducing production variability $[17,18]$. Perhaps the single best measure for tracking lean progress is total product cycle time (total time that Lean is called as a Machine that Changed the World [14]; a book which first highlighted Japanese production methods as compared to traditional Western mass production systems; it also highlighted the superior performance of the former. The follow-on book, Lean Thinking: Banish Waste and Create Wealth in Organization [16], is equally a key step in the history of lean as it summarizes the lean principles which 'guide action' [19-23]. Table 2 defines the eight types of wastes that are seen in Toyota manufacturing industries and commonly experienced in today's manufacturing industries causing high cost of production.

The Toyota Company identified the eight forms of wastes but other books like [13] classified the wastes into seven main issues keeping the wastes stated by TPS as they are there and overlooking human resources specifically.

\begin{tabular}{|c|c|c|}
\hline S No & Form & Description \\
\hline 1 & Overproduction & $\begin{array}{l}\text { Producing more than it is need or and used. } \\
\text { production ahead of demand }\end{array}$ \\
\hline 2 & Human resources & Not using peoples mind and getting them involved \\
\hline 3 & Transportation & $\begin{array}{l}\text { Moving tools/materials to the point of use. moving } \\
\text { products that are not actually required to perform } \\
\text { the processing }\end{array}$ \\
\hline 4 & Inventory & $\begin{array}{l}\text { Materials or information. Includes WIP and } \\
\text { Finished goods. all components, work in process, } \\
\text { and finished product not being processed }\end{array}$ \\
\hline 5 & Motion & $\begin{array}{l}\text { Movement of people (walking, riding) as well as } \\
\text { smaller movements more than required }\end{array}$ \\
\hline 6 & Corrections/defects & This includes rework or fixing of products. \\
\hline 7 & Over-Processing & $\begin{array}{l}\text { Additional work above the requirements and/or } \\
\text { needs. resulting from poor tool or product design } \\
\text { creating activity }\end{array}$ \\
\hline 8 & Waiting & $\begin{array}{l}\text { Time delays for materials, information or people. } \\
\text { waiting for the next production step, interruptions } \\
\text { of production during shift change }\end{array}$ \\
\hline
\end{tabular}

Table 2: Eight forms of waste identified by Toyota [13].

Lean Thinking starts with the customer and the definition of value [13]. Therefore, as a manufacturing process is a vehicle to deliver value (a product) to a customer, the principles of lean thinking should be applicable to the Process Industries and the specific manufacturing processes within that industry [13].

The Lean Enterprise Research Centre (LERC) at Cardiff Business School highlighted that for most production operations $[8,14,15,16]$ :

- $5 \%$ of activities add value;

- $35 \%$ are necessary non-value activities;

- $60 \%$ add no value at all.

Therefore, there is no doubt that the elimination of waste represents a huge potential in terms of manufacturing improvements following the key points to: identify both waste and value; develop knowledge management base; realize that sustainable improvement requires the buy in of the people operating the processes and managing the business, and therefore a culture of continuous improvement.

Five key principles those should be viewed and practiced in conjunction to success in lean, namely given in the following discussion [16]:

- Value - the end customer's perspectives on product/service capabilities, price, performance and availability.

- Elimination of waste through value streamline, that is, all activities that do not add value and for which the end customer is unwilling to pay

- Managing continuous flow of product, information through the system on a just-in-time basis avoiding batches, waiting, and down time between activities - Using pull/Kanban, producing only what customers' needs

They stressed that the lean is not mainly focus in the production line, but also relates to activities from product development, procurement and manufacturing over to distribution.

There are nine green principles which are necessary in assessing lean performance, namely: elimination of waste, continuous improvement, zero defects, JIT deliveries, pull of materials, multifunction teams, decentralization, integration of functions and vertical information [24].

\section{Key tools, benefits and critical success factors of lean}

Key tools and techniques used to solve any problems of manufacturing industries and their benefits at the end of their solution within the 'lean' system are given in Table 3.

Critical Success Factors in lean thinking are: Top Management

\section{Key tools and techniques of lean}

Kanban: a visual signal to support flow by 'pulling' product through the manufacturing process as required by the customer

Visual management and 5 S's: a visual housekeeping technique which devolved control to the shop floor

Visual control: a method of measuring performance at the 'shop floor' which was visual and owned by the operator team

Poke yoke: an 'error-proofing' technique more robust processes (as measured by less errors and therefore less rework)quality improvement

Takt time and SMED (single minute Reduce Space utilizations, save exchange of dies): a changeover reduction technique

\begin{tabular}{l|l} 
Kaizen Blitz, and spaghetti map Improve process and easy works
\end{tabular}

Table 3: Lean tools and benefits [13]. 
Support, focus on the Goal, focus on the long Term, involve everyone at all levels of the organization and involve customers and supplies.

This key factor for the success of lean implementation helps an organization to exercise the lean principles and philosophy in their industries [25]. The following Table 4 shows the difference between traditional organization and lean organization depending on the given concepts. The concepts are applicably exercised in the lean industries if only the success factors are handled properly to make it different from traditional approach. Figure 1 is a force field diagram which shows some of the drivers and resistors within the manufacturing sector of the process industries. It is only when the specific driving forces for an organization are greater than the opposing forces that the change will occur.

The ultimate sustainability then requires additional supporting forces to further reduce and eliminate opposition. The main opponents of the infant stage manufacturing industries in Ethiopia are the challenges of unwilling to customize lean philosophy and principles.

Chemical manufacturing industries like cement, plastics, paints, oils, gases, petrochemicals, additive chemicals, basic chemicals, Pharmaceutical, etc. are facing lean problems. Within the process industries specific sectors have been under increasing pressure of lean: Chemical Industry: the continuing pressure on the cost base and Pharmaceutical manufacturing: the pressure on the supply chain has increased as there are more external competitive pressures for manufacturers to deliver new, safe efficacious drugs quicker than ever before.

\section{Lean chemical management and application}

To develop lean thinking further within organization it is recommended to communicate the sustainable successes from the implementation within manufacturing; to review the value chain for a specific customer or set of customers; to review the business processes as well as the physical processes and apply the same structured data rational process, based on using cross-functional teams empowered to implement change; and keep looking for waste, keep checking up on the value one deliver to customers, keep controlling the flow-make it a part of a business culture.

\begin{tabular}{|c|c|c|}
\hline Concepts & $\begin{array}{l}\text { Traditional } \\
\text { organization }\end{array}$ & Lean organization \\
\hline Inventory & $\begin{array}{l}\text { An asset, as defined by } \\
\text { accounting terminology }\end{array}$ & $\begin{array}{l}\text { A waste- ties up a capital \& } \\
\text { increases processing lead-time }\end{array}$ \\
\hline $\begin{array}{l}\text { Ideal economic } \\
\text { order quantity and } \\
\text { batch size }\end{array}$ & $\begin{array}{l}\text { Very large- run large } \\
\text { batch sizes to make up } \\
\text { for process downtime }\end{array}$ & $\begin{array}{l}\text { One- continuous efforts are } \\
\text { made to reduce down time to } \\
\text { zero }\end{array}$ \\
\hline People utilization & $\begin{array}{l}\text { All people must be busy } \\
\text { at all time }\end{array}$ & $\begin{array}{l}\text { Because work is performed } \\
\text { based directly upon customer } \\
\text { demand, people might not be } \\
\text { busy }\end{array}$ \\
\hline Process utilization & $\begin{array}{l}\text { Use high speed } \\
\text { processes and run them } \\
\text { all the time }\end{array}$ & $\begin{array}{l}\text { Processes need to only be } \\
\text { designed to keep up with } \\
\text { demand }\end{array}$ \\
\hline Work scheduling & $\begin{array}{l}\text { Build products to } \\
\text { forecast }\end{array}$ & Build products to demand \\
\hline Labor costs & Variable & fixed \\
\hline Accounting & $\begin{array}{l}\text { Traditional (functional) } \\
\text { departments }\end{array}$ & Cross-functional teams \\
\hline Quality & $\begin{array}{l}\text { Inspect/sport work at } \\
\text { end of process to make } \\
\text { sure we find all errors }\end{array}$ & $\begin{array}{l}\text { Processes, products, and } \\
\text { services are designed to } \\
\text { eliminate errors }\end{array}$ \\
\hline
\end{tabular}

Table 4: Comparisons of traditional and lean organization [13].

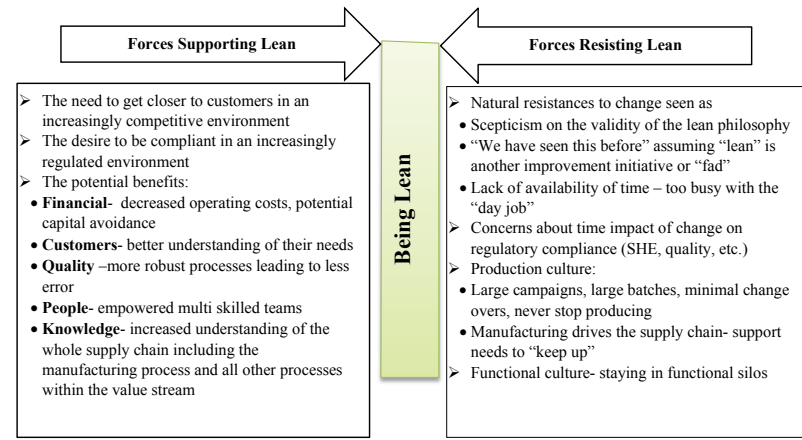

Figure 1: The forces opposing and driving a change to 'lean [13]

Many Lean manufacturing strategies including right-sized equipment and containers, just-in-time (JIT) delivery, point-of-use storage, $6 \mathrm{~S}$ (5S+Safety), kitting, and visual controls can dramatically reduce chemical use, waste, and risk in principle. Example chemical management strategies that support Lean goals include:

- JIT and Chemical Management Services: Having chemicals delivered when it needs them in the amounts that it needs supports Lean goals while also reducing.

- Risks and wastes. Contracting with companies that provide chemical management services can remove even more waste.

- Right-Sizing: Limit unnecessary use of chemicals and increase process efficiency by making equipment and containers the right size for the task.

- Applying Lean to Hazardous Waste Management: Use Lean to improve chemical and waste management "support" processes, such as waste-collection processes and compliance-reporting activities.

- Point-of-Use Storage: Adopt proper maintenance and control procedures to prevent regulatory compliance and worker health and safety issues associated with point-of-use storage of chemicals.

- Visual Management: Reinforce best practices for using and disposing of chemicals and hazardous wastes with visual controls, standard work, 6S (5S+Safety), and Total Productive Maintenance.

\section{Driving out chemical wastes with lean events}

Value stream mapping events and kaizen rapid process improvement events are very effective ways to identify and eliminate chemical wastes. Strategies include:

- Value Stream Mapping Events: Add chemical metrics or show environmental inputs and outputs on the process boxes on value stream maps, as a way to discover new process improvement opportunities.

- Kaizen Events: Involve environmental health and safety (EHS) personnel strategically in kaizen events, ask questions to identify the root causes of chemical wastes, and target certain kaizen events on chemical wastes [26].

Making a value stream: the design and implementation of lean: The following Table 5 shows how the three principles of lean supported by the enabling principles, can deliver step change business benefits and ongoing incremental benefits [26,27]. 
Citation: Jilcha K, Kitaw D (2015) Lean Philosophy for Global Competitiveness in Ethiopia Chemical Industries: Review. J Comput Sci Syst Biol 8: 304-321. doi:10.4172/jcsb.1000205

\section{Lean comparison with other process improvement techniques}

There are so many principles and methodologies for manufacturing process improvement with specific applications, features and implementation procedures. Of course, even if most of these principles focus on process improvement, the central objective to be achieved greatly varies among each other (Table 6) [24].

\section{Implementation characteristics}

Lean Enterprise System: Top-down directive process involving, strong leadership, support and engagement; using structured process (frameworks, roadmaps) for enterprise-level continuous improvement and planned systemic change; Use of outside experts (providing facilitation, mentoring, training, implementation services) or internally managed process.

Total Quality Management (TQM): Top-down directive process involving heavy multi-level management participation; using a portfolio of practices, tools and techniques to implement continuous

\begin{tabular}{|c|c|c|}
\hline Tool & Description & Typical use \\
\hline Force field diagram & $\begin{array}{l}\text { A tool allows analysis of forces supporting or resisting a particular } \\
\text { change }\end{array}$ & $\begin{array}{l}\text { When looking at a potential design, looking at implementation planning } \\
\text { for a change following design, }\end{array}$ \\
\hline $\begin{array}{l}\text { Input-process-output } \\
\text { (IPO) diagram }\end{array}$ & $\begin{array}{l}\text { A basic flow chart tool mapping inputs, processes, and outputs. } \\
\text { Based on the required outputs, the appropriate process can be } \\
\text { defined and the required inputs specified }\end{array}$ & $\begin{array}{l}\text { To design team section at any stage of the implementation of lean, } \\
\text { e.g. Data collection day, kaizen day (implement a change in one day), } \\
\text { implementation planning }\end{array}$ \\
\hline Process flow mapping & A map showing each process steps in the value stream & $\begin{array}{l}\text { A data collection activity, also used to analyze VA(value add) and NVA } \\
\text { (non-value add) steps and as a tool for redesign }\end{array}$ \\
\hline Time-value mapping & A map of the time taken for each process steps in the value stream & $\begin{array}{l}\text { A data collection activity, also used to analyze VA(value add) and NVA } \\
\text { (non-value add) steps and as a tool for redesign }\end{array}$ \\
\hline Spaghetti diagraming & $\begin{array}{l}\text { A map of the physical path taken by a product as it passes down the } \\
\text { value stream }\end{array}$ & A data collection activity \\
\hline Five whys & $\begin{array}{l}\text { Taiichi Ohno (Womack, et.al., 1990) had a practice of asking why five } \\
\text { times when ever problems were found. In this way the root causes } \\
\text { were solved rather than the symptom }\end{array}$ & $\begin{array}{l}\text { As a part of the data analysis so that the root cause problems can be } \\
\text { solved in the design phase }\end{array}$ \\
\hline Five S's & $\begin{array}{l}\text { Five activities used to create a workplace suited for visual control } \\
\text { and lean practices: Sort (Seiri)- separate required from unnecessary } \\
\text { tools and remove the latters, Straighten (Seito)- arrange tools for } \\
\text { ease of use, Sweep Seiso)- clean up, Standardize (Seiktsu)- do } \\
\text { the above regularly, Self-discipline (Shitsuke)-get into the habit of } \\
\text { following the } 1^{\text {st }} \text { four s's. }\end{array}$ & $\begin{array}{l}\text { Can be used at start of lean induction to break down barriers and get } \\
\text { a lean to own a workspace, often used during Kaizen as a workplace } \\
\text { layout and tidiness is often an issue which causes waste (un able to } \\
\text { find the right equivalent, use what is there, loss key paper work and } \\
\text { so on) }\end{array}$ \\
\hline Risk Assessment & $\begin{array}{l}\text { A structured assessment of what could stop the achievement of } \\
\text { specific objectives and how this can be mitigated }\end{array}$ & $\begin{array}{l}\text { Assessment of design prior to implementation as a final challenge of } \\
\text { the design, assessment of the issues post -implementation -looking } \\
\text { specifically at what would stop sustainability of the change. }\end{array}$ \\
\hline Kaizen & $\begin{array}{l}\text { An improvement activity to create more value and remove waste. } \\
\text { Commonly called a breakdown kaizen }\end{array}$ & $\begin{array}{l}\text { Kaizen workshop are a common method to kick-off the start of large } \\
\text { set up change within an area or value stream, kaizen would actually } \\
\text { start with data collection and continues to do some data analysis, } \\
\text { design, and even implementation }\end{array}$ \\
\hline Kanban & $\begin{array}{l}\text { Japanese for 'signboards'. This is a visual shop floor pull system } \\
\text { which means that each supplying work center does not make } \\
\text { anything until the next work center request supply }\end{array}$ & This is a design solution to materials flow problems within process \\
\hline
\end{tabular}

Table 5: Sample Lean toolkit $[26,27]$.

\begin{tabular}{|c|c|c|c|c|c|c|}
\hline $\begin{array}{l}\text { Approach } \\
\text { Key dimensions }\end{array}$ & $\begin{array}{l}\text { Lean Enterprise } \\
\text { System }\end{array}$ & $\begin{array}{l}\text { Total Quality } \\
\text { Management (TQM) }\end{array}$ & Six Sigma & $\begin{array}{l}\text { Theory of } \\
\text { Constraints } \\
\text { (TOC) }\end{array}$ & $\begin{array}{l}\text { Agile } \\
\text { Manufacturing }\end{array}$ & $\begin{array}{l}\text { Business Process } \\
\text { Reengineering } \\
\text { (BPR) }\end{array}$ \\
\hline History & $\begin{array}{l}\text { Since late 1940s } \\
\text { (emphasis on } \\
\text { developments since } \\
\text { mid-1990s) }\end{array}$ & Since early 1980 s & Since mid-1980s Since & mid-1980s Since & early 1990s Since & early 1990s \\
\hline Goal & $\begin{array}{l}\text { Deliver value to multiple } \\
\text { stakeholders } \\
\text { Build long-term } \\
\text { dynamic network-wide } \\
\text { capability for sustained } \\
\text { competitive advantage }\end{array}$ & $\begin{array}{l}\text { Meet customer } \\
\text { expectation } \\
\text { Improve profitability and } \\
\text { shareholder value }\end{array}$ & $\begin{array}{l}\text { Increase customer } \\
\text { satisfaction } \\
\text { Create economic } \\
\text { wealth (higher } \\
\text { profitability and } \\
\text { shareholder value }\end{array}$ & $\begin{array}{l}\text { Maximize throughput } \\
\text { Improve net profits }\end{array}$ & $\begin{array}{l}\text { Enhance enterprise } \\
\text { flexibility and } \\
\text { responsiveness } \\
\text { Thrive in a fast-paced, } \\
\text { uncertain, environment }\end{array}$ & $\begin{array}{l}\text { Improve customer } \\
\text { satisfaction } \\
\text { Enhance enterprise } \\
\text { performance }\end{array}$ \\
\hline $\begin{array}{l}\text { Defining } \\
\text { Feature }\end{array}$ & $\begin{array}{l}\text { Mutually supportive } \\
\text { and enforcing set of } \\
\text { principles, practices } \\
\text { and methods for } \\
\text { evolving efficient and } \\
\text { flexible enterprises as } \\
\text { networked systems } \\
\text { creating value for } \\
\text { multiple stakeholders }\end{array}$ & $\begin{array}{l}\text { Evolving system of } \\
\text { precepts, practices, } \\
\text { tools and techniques } \\
\text { for improving quality to } \\
\text { satisfy customer needs } \\
\text { \& expectations }\end{array}$ & $\begin{array}{l}\text { Structured methods, } \\
\text { practices and tools for } \\
\text { reducing all sources of } \\
\text { variation in order to } \\
\text { improve quality, satisfy } \\
\text { customer needs, and } \\
\text { improve the bottom-line }\end{array}$ & $\begin{array}{l}\text { Set of ordered } \\
\text { practices, methods and } \\
\text { tools for improving } \\
\text { throughput in } \\
\text { production systems in } \\
\text { order to maximize } \\
\text { financial performance, } \\
\text { by viewing the } \\
\text { production system as } \\
\text { "chains of } \\
\text { interdependencies" }\end{array}$ & $\begin{array}{l}\text { Future-looking, } \\
\text { aspirational, set of } \\
\text { concepts and practices } \\
\text { aimed at defining the } \\
\text { next industrial } \\
\text { paradigm beyond lean } \\
\text { enterprise ideas and } \\
\text { flexible production } \\
\text { systems }\end{array}$ & $\begin{array}{l}\text { Manifesto for turning } \\
\text { the } \\
\text { prevailing industrial } \\
\text { system on its head; a } \\
\text { manifesto for } \\
\text { fundamental rethinking } \\
\text { and radical redesign of } \\
\text { core enterprise } \\
\text { processes }\end{array}$ \\
\hline
\end{tabular}




\begin{tabular}{|c|c|c|c|c|c|c|}
\hline Core Concepts & $\begin{array}{l}\text { Adopt a holistic view } \\
\text { of the networked } \\
\text { enterprise } \\
\text { Stress long-term } \\
\text { thinking } \\
\text { Deliver customer pulled } \\
\text { best lifecycle value } \\
\text { Eliminate waste } \\
\text { towards the goal of } \\
\text { creating value } \\
\text { Ensure stability and } \\
\text { synchronized flow } \\
\text { Develop collaborative } \\
\text { relationships and } \\
\text { mutually-beneficial } \\
\text { network-wide } \\
\text { governance } \\
\text { mechanisms } \\
\text { Foster a culture of } \\
\text { continuous learning } \\
\text { Evolve an efficient, } \\
\text { flexible \& adaptive } \\
\text { enterprise }\end{array}$ & $\begin{array}{l}\text { Understand and fulfill } \\
\text { customer expectations } \\
\text { Concentrate on process } \\
\text { management to reduce } \\
\text { sources of variation } \\
\text { Focus on continuous } \\
\text { quality improvement } \\
\text { Ensure heavy } \\
\text { leadership involvement } \\
\text { Establish close links to } \\
\text { customers \& suppliers } \\
\text { Develop an "open" } \\
\text { organization } \\
\text { Foster worker training, } \\
\text { empowerment and } \\
\text { fulfillment }\end{array}$ & $\begin{array}{l}\text { Adopt customer } \\
\text { focused culture } \\
\text { Reduce all sources of } \\
\text { variation } \\
\text { Pursue disciplined, } \\
\text { structured, approach to } \\
\text { process improvement } \\
\text { Practice proactive, } \\
\text { data-driven, } \\
\text { management } \\
\text { Emphasize teamwork }\end{array}$ & $\begin{array}{l}\text { Improve workflow } \\
\text { (throughput) in the } \\
\text { production system } \\
\text { Concentrate on } \\
\text { key leverage points } \\
\text { (constraints) offering } \\
\text { greatest performance } \\
\text { improvements } \\
\text { Protect production line } \\
\text { against interruptions } \\
\text { Ensure people learn } \\
\text { better and faster }\end{array}$ & $\begin{array}{l}\text { Anticipate and meet } \\
\text { customer needs } \\
\text { Deliver tailored } \\
\text { solutions to customers } \\
\text { Evolve adaptive, } \\
\text { flexible \& efficient } \\
\text { enterprise } \\
\text { Establish virtual } \\
\text { organizations } \\
\text { Enhance ability to } \\
\text { thrive in a fast-paced \& } \\
\text { uncertain environment }\end{array}$ & $\begin{array}{l}\text { Reinvent enterprise } \\
\text { through fundamental } \\
\text { rethinking of enterprise } \\
\text { processes } \\
\text { Pursue radical ("clean } \\
\text { sheet") redesign of } \\
\text { existing business } \\
\text { processes } \\
\text { Seek breakthrough } \\
\text { process solutions }\end{array}$ \\
\hline
\end{tabular}

Table 6: Comparison of lean with other improvement Enterprise [24].

improvement; Use of outside experts (providing facilitation, mentoring, training, implementation services) or internally managed process.

Six Sigma: Top-down directive process involving structured management engagement (project champions, sponsors); Using DMAIC (Define, Measure, Analyze, Improve, Control) as the dominant implementation method; largely internally managed process with support/facilitation by outside experts [24].

Theory of Constraints (TOC): Top-down directive process involving management participation; Using structured process employing focusing steps(to remove constraints), ten-step Decalogue for system-wide management, and "drum-buffer-rope" production scheduling method for managing production line; Mostly internally managed process with support/facilitation by outside experts.

Agile Manufacturing: Top-down directive process led by top management; Emphasis on enterprise integration, training and education, and empowered teams; Building effective information infrastructure; forming virtual organizations; Mostly internally managed process, with possible support from outside experts.

Business Process Reengineering (BPR): Top-down directive process involving management participation (e.g., as process owners); generally pursuing a structured multi-step implementation process (Mobilization, Diagnosis, Redesign, Transition); Facilitation by outside experts or internally managed process $[19,24,28]$.

\section{Gaps identified in literature review}

Lean manufacturing has been practiced in Toyota Production system in which it was a discrete production type. But as the studies indicate that lean chemical is not exercised in most process or chemical industries in organized manner where it was expected as continues production system even in developed economy. Specially, it is troublesome to use lean chemical and the tools used to implement the philosophy in developing economy. The other challenge and barrier in practicing lean chemical is due to infant stage of chemical industry development and their production contribution to the global competitiveness environment being almost insignificant. Industries in many developing countries are working on old and obsolete techniques of manufacturing.

There are many tools suggested for the implementation of Lean manufacturing. However, the suitability of these tools depends on requirements and type of production systems such as discrete and continuous processes. The implementation of this lean principle depends on available technology, market structure, market condition, culture, finance, management trend, resources and many others factors.

For instance, the material management, outdated machinery maintenance, raw material supply, etc. are some of the problems those create wastes in chemicals. The use of JIT philosophy is predominant in many literatures. However, the use of JIT in developing economy is not as profitable as that of developed economy due to the fact that high inflation rate, unstructured markets, lack of adequate infrastructure; high and unknown lead time to import raw chemical items and many other barriers exists.

On the other hand, finance to the raw material, high pilferage of materials, lack of adequate store space, lack of environmental protection and many other problems associated with inventory when using JustIn-Case inventory policy is another challenge. Research gap has been identified on the suitability of lean chemicals or process philosophy tools.

The other gap is that lean most of the time focuses on the minimization of waste like waste of time, resources, energy, labor and inventory control than focusing on quality of products even though it does not mean to compromise quality. The other gap found is that as resource utilization getting efficient and effective, the labor force reduction results in unemployment of the citizens. Lean in Ethiopian context is the difficult scenario of managements of industries.

The concept of lean manufacturing might look easy but its implementation is not an easy task. The introduction of lean manufacturing into an organization tends to change its working culture. Such changes are considered to be barriers to the implementation process of lean manufacturing. Changes occurring in the organization tend to change the workers in the organization. Much hard work has to be done to recognize these changes in the organization.

\section{Chemical Industries Competitiveness Scenario}

\section{Introduction}

Chemicals are an integral part of daily life in today's world. There is hardly any industry where chemicals are not used and there is no 
single economic sector where chemicals do not play an important role. These chemicals are used in a wide variety of products and processes and while they are major contributors to national and world economies, their sound management throughout their lifecycle is essential in order to avoid significant and increasingly complex risks to human health and ecosystems and substantial costs to national economies [29].

The main classification of chemical sectors may be classified in to Basic Chemicals, Specialty chemicals, knowledge chemicals, cement and non-metallic products and consumer products. These categories are also dependent on the country's developmental stage as well as developmental directions. In countries where the economic base has good diversification the specialization in chemical sector is high narrowing the classifications. In such cases the classification is limited to basic chemicals, specialty, knowledge chemicals and consumer products. But in the countries where the economic diversity is limited like Ethiopia, the classification include all the categories taking in to consideration the fact that, when economic diversification existed some categories will stand by their own as a sector. So that the chemical sector only focuses on the three categories well exercised in the countries where diversification is achieved.

The chemical sectors one of the most influential industries worldwide. This is because many industries - the plastics industry, food industry, automobile industry, glass industry, building industry, and many more -are highly dependent on chemical materials. The chemical industry includes, first of all, all inorganic chemistry, agricultural chemistry, and petrochemicals. Further, the plastics and rubber industry, and the paper industry are part of this category. Although it is very close to chemistry, pharmaceuticals are a separate branch in this categorization. Figures on the plastics and rubber industry are also among the top chemical statistics.

\section{Classification of chemical products}

Basic/bulk chemicals: Basic/bulk chemicals are both organic and inorganic chemicals that are used by other industries as a raw material for further processing in order to be converted to end-products. They consists of high-volume chemicals: the olefins (ethylene, propylene, and butadiene), the aromatics (benzene, toluene, and xylenes), and methanol. Secondly it consists of a larger number of chemicals made from these starting materials, sometimes in combination with inorganic chemicals.

Specialty chemicals: Specialty chemicals are defined as a "group of relatively high value, low volume chemicals known for their end user applications and/ or performance enhancing properties. It include chemical additives and auxiliaries; paints, inks, dyes, and pigments; coatings and sealants, and other chemicals.

Knowledge chemicals: Knowledge chemicals are those chemicals consisting of highly differentiated chemicals and biological substances used to induce specific outcomes in humans, animals, plants and other life forms. The segment is characterized by a high degree of research, intellectual capital and skilled man power. The segment incorporates agrochemicals, pharmaceuticals and biotechnology sub segments.

Consumer products: Consumer Products are formulated chemical products sold directly to consumers. Examples include cleaning products and personal care products.

Cement and non-metallic products: This category comprises cement and products which are derived mineral resources and are processed in industries like glass, ceramics, calcium carbonate and calcium oxide. This category is a bit different from the international chemical sector definition but for the Ethiopian case since the chemical sector is at the infant stage it is found to be important to consider it as one subsector for the starting phases of diversification in the next thirteen years [30] (Table 7).

\section{Global competitiveness of chemical industries}

In order to understand Ethiopian chemical industry it becomes pertinent to know the characteristics of the global chemical industry, the challenges it faces and the trends in the market so as to know how this knowledge based industry that supplies to almost all sectors of the economy thrives.

In response to the growing demand for chemical-based products and processes, the international chemical industry has grown dramatically since the 1970s. Global chemical output (produced and shipped) was valued at US\$171 billion in 1970. By 2010, it had grown to $\$ 4.12$ trillion [14].

Global chemical industry is estimated to be USD 4.2 trillion and considered one of the fastest growing sectors of the manufacturing industry. Global sales in this sector in 2010 were an estimated USD 3.5 trillion. It grew at a rate of $9 \%$ during 2004-2008 but witnessed a dramatic downturn in 2008-09 due to the global economic collapse. Global chemical production continues to be dominated by US and China, which have a 19.5 and $18.5 \%$ share of the global market, respectively [31]. Region wise, Europe and Asia dominate chemical imports with nearly 38 and $37 \%$ of the global imports of chemicals in 2009, respectively. Asia has become the leading market for the chemical industry globally, accounting for an estimated $38 \%$ of global sales followed by the EU and North American Free Trade Agreement (NAFTA) accounting for $29 \%$ and $21 \%$ respectively. Considering all the influences arose in the $20^{\text {th }} \mathrm{c}$. the chemical industry is increasingly moving eastwards in line with satisfying these and to leverage greater manufacturing competitiveness of emerging Asian economies and to serve the increasing local demands. Over the last decade, BRICS

\begin{tabular}{|c|c|c|}
\hline $\begin{array}{l}\text { Industry } \\
\text { segments }\end{array}$ & Characteristics & $\begin{array}{l}\text { Constituent } \\
\text { industries }\end{array}$ \\
\hline Basic & $\begin{array}{l}\text { High volume, low value-added } \\
\text { Limited product differentiation across } \\
\text { manufactures } \\
\text { High entry barriers on account of high } \\
\text { capital spend and stringent regulations }\end{array}$ & $\begin{array}{l}\text {-Petrochemicals } \\
\text {-Fertilizers \&- } \\
\text { Inorganic chemicals } \\
\text {-Man-made fibers } \\
\text { \&- Chlor-Alkal }\end{array}$ \\
\hline Specialty & $\begin{array}{l}\text { High product differentiation and value } \\
\text { addition } \\
\text { Typically smaller production units with more } \\
\text { flexibility } \\
\text { Low capital investments levels }\end{array}$ & $\begin{array}{l}\text { - Dyes \& pigments } \\
\text { - Leather chemicals } \\
\text { - Construction } \\
\text { chemicals } \\
\text { - Food \& Polymer } \\
\text { additives } \\
\text { - Industrial gases }\end{array}$ \\
\hline Knowledge & $\begin{array}{c}\text { Differential chemical and biological } \\
\text { substances used to induce specific out } \\
\text { comes in humans, animals, plants and } \\
\text { other life forms } \\
\text { High investments in R\&D and marketing }\end{array}$ & $\begin{array}{l}\text { - Agro-chemicals } \\
\text { - Pharmaceuticals } \\
\text { - Biotechnology }\end{array}$ \\
\hline $\begin{array}{l}\text { Consumer } \\
\text { Products }\end{array}$ & $\begin{array}{l}\text { Products made for direct or immediate } \\
\text { application of a customer/end user }\end{array}$ & $\begin{array}{l}\text { Personal care } \\
\text { ingredients } \\
\text { Cleaning products }\end{array}$ \\
\hline $\begin{array}{l}\text { Plastic } \\
\text { and rubber } \\
\text { products }\end{array}$ & - & $\begin{array}{l}\text { Polymers, synthetic } \\
\text { fibers } \\
\text { Tire }\end{array}$ \\
\hline $\begin{array}{l}\text { Cement \& } \\
\text { Nonmetallic } \\
\text { products }\end{array}$ & $\begin{array}{c}\text { Mineral based resource is used } \\
\text { Relatively moderate capital investment } \\
\text { needed }\end{array}$ & $\begin{array}{l}\text { Cement } \\
\text { Calcium carbonate } \\
\text { Ceramics and glass }\end{array}$ \\
\hline
\end{tabular}

Table 7: Summery of industry segments. 
Citation: Jilcha K, Kitaw D (2015) Lean Philosophy for Global Competitiveness in Ethiopia Chemical Industries: Review. J Comput Sci Syst Biol 8: 304-321. doi:10.4172/jcsb.1000205

countries (Brazil, Russia, India, China, and South Africa) have far exceeded the world growth rates of the Organization for Economic Cooperation and Development (OECD) countries. For example, from 2000 to 2010, chemical production in China and India grew at an average annual rate of $24 \%$ and $14 \%$, respectively, whereas the growth rate in the US, Japan and Germany was between 5 to $8 \%[29,30]$.

The chemical sector demand shows significant change in developing countries unlike the classical thoughts which emphasizes on the market of developed countries. Annual global chemical sales doubled over the period 2000 to 2009 compared to the previous years, OECD's share decreased from $77 \%$ to $63 \%$ and the share of the BRIICS countries (Brazil, Russia, India, Indonesia, China, and South Africa) increased from $13 \%$ to $28 \%$ [29]. These indicate that the shift of the chemical industries to the eastern countries is driven by the consideration of rise in global market.

Considering the continuous increase in life standard and consumer expectation with respect to safety, environmental issues and quality in the western countries relatively tough regulations has arose in restricting the production of chemical industries which in turn forced the chemical industries to look for relatively loose environment [32].
Moreover, visualizing the significant impact on employment, the search for cheap work force in comparison with the western world had also contributed for the gradual shift of the sector to the east (Table 8).

Of these specialty chemicals are expected to grow at a faster pace in the next few years in comparison to their global counterparts [33].

\section{Growth and competitiveness of chemical manufacturing}

One country to be competitive, it should satisfy the main drivers of global manufacturing competitiveness forces given in the following figure (Figure 2). These forces shown in figure are measure for global competitiveness of a company and there by which helps it to use all the lean manufacturing system in reducing wastes of all driving forces [34].

The competitive drivers are very essential points in lean consideration to eliminate wastes and increase efficiency of competitiveness in the global scenario. Germany, US, Japans, China, Brazil, India are competing for the global manufacturing. The china's economy is booming up due to the strong act on the competitive driver's forces properly $[18,35]$. China is the biggest chemicals producer in 2010. In 2010, the 30 largest chemical-producing countries had a combined turnover of $€ 2103$ billion [36,37] (Figure 3 and Table 9).

\begin{tabular}{|c|c|c|c|c|}
\hline Types of chemical & Base chemicals & Pharmaceuticals & Specialty chemicals & Bio-technology \\
\hline Shares $\%$ & $45 \%$ & $27 \%$ & $22 \%$ & $5 \%$ \\
\hline
\end{tabular}

Table 8: Share of chemicals in global industries.

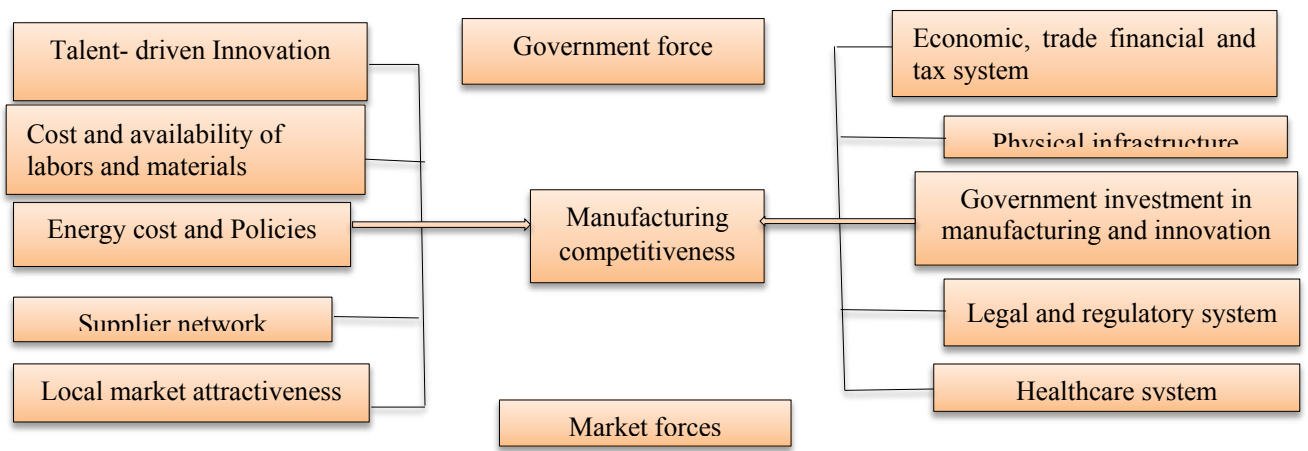

Figure 2: Drivers of global manufacturing competitiveness [34]

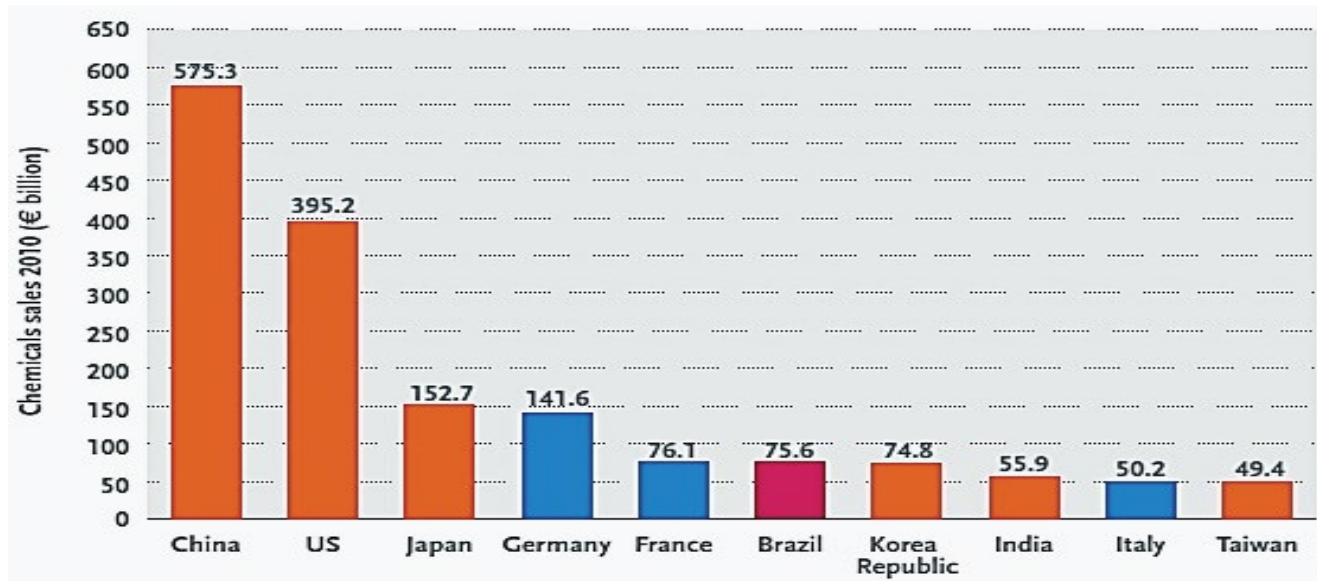

Figure 3: World chemicals industry profile [37]. 
The European Union was the leading exporter and importer of chemicals in the world, accounting for $41 \%$ of global trade, defined as the total value of exports plus imports. In 2011, worldwide, it was estimated that world sales of chemicals amounted to over $\$ 3500$ billion (Table 3). This means every man, woman and child in the world, on average, uses $\$ 500$ worth of chemicals a year. Of course the main users of the chemicals are in the developed countries with each person using approximately $\$ 1200$ worth of chemicals annually (Table 10 ).

\section{African chemical scenario}

Despite the fact that it's small contribution to GDP, the industrial sector supplies significant amounts of consumer goods to both the domestic and international markets. The main manufacturing products are textiles, foodstuffs, beverages, leather and non-metallic products in Africa. The industrial sector is progressively gaining ground in many African countries. It now represents 4 to $32 \%$ of the national GDPs in most African countries. Having been dominated by food industries for a long time, the sector has rapidly diversified due to the growth of strategic chemical sectors such as petroleum, pesticide and pharmaceuticals.

To meet its developmental needs, Africa imports large amounts of various types of chemicals for industrial, domestic and agricultural purposes, as well as for cosmetics, food, plastics, laboratory and petroleum. On the other hand, some countries have successfully diversified their economic activities by carving out special niches in textiles, financial services, and information and communication technologies. These are importing trend makes Africa not to be competent to global chemical market share scenario.

As United Nation Economic Commission for Africa (UNECA) said, although Africa's contribution to value-added production of chemicals is small, current trends suggest that its contribution to global production will continue to grow. Given that projections indicate that manufacturing in general, not just chemical manufacturing only, could be relocated from the Organization for Economic Cooperation and Development (OECD) countries to developing countries in the medium term, this sector can be expected to grow further. The most advanced chemical industries in Africa are found in the Northern, Western and Southern regions. Chemical and petroleum industries currently account for 3 to $42 \%$ of the GDP in African countries [38]. In general however, apart from the major oil exporting countries (Angola, Nigeria, Libya, Egypt and Sudan, and the emerging ones, Ghana and Uganda), the chemical industry still relatively forms a small share of GDP in many African countries (UNECA). The development of chemical industries in these sub-regions has been facilitated by access to larger markets and the presence of natural resources that support growth in this sector, notably natural gas and oil, and the presence of well-developed infrastructure that supports industrial growth in general.

More African countries are importing chemicals and products containing chemicals, due to trade liberalization and creation of free trade industrial zones. Therefore African chemical competitiveness still remain at infant stage when compared with the rest of the worlds. In the West African region, Nigeria is the main producer and user of chemicals. In the south, the prime market and producer is South Africa.

The chemical markets in Africa are largely targeted at meeting local needs for chemical feedstock's and intermediates rather than being export orientated. In the case of the Mediterranean countries, the proximity to markets has led to a greater export focus than in other areas. Petrochemical commodities, polymers and fertilizers are the main products of the African chemicals industry [UNECA). In general African chemical manufacturing competitiveness is very low in regard to the $12^{\text {th }}$ international competitiveness pillars factors for competiveness measure.

\section{Ethiopian chemical scenario}

There are very few basic chemical industries that could serve as part of the foundation for development of the sub sector. Most of the other establishments in the sub sector produce chemical products by further processing (adding value) to imported chemical products. The country's demand of chemical products is met mainly through import. There is an increasing quantity of chemicals and chemical products which is being imported every year for which a considerably high amount of foreign exchange is being spent. As shown from Table 10, the import of chemical and chemical products has shown an average growth rate of $15.74 \%$ during the period (2004-2011) and the average CIF $[30,33]$ (Table 11).

Considering the basic definition given, the chemical Industry in Ethiopia can be classified as Base chemical which includes fertilizer, inorganic and organic chemical, knowledge chemicals, specialty chemicals, Rubber and plastic and cement and non-metallic products (Table 12).

Chemical imports of Ethiopia in line with other worlds: To see share of Ethiopian chemical imports with the world, Africa and COMESA, the following Table 13 indicates the contribution of the country imports. As we can see from the above Table 13 the global import of chemical and chemical products increased during the period 2004-2011 with an average rate of $10.64 \%$ to reach 1.65 trillion USD,

\begin{tabular}{|c|c|c|c|c|c|c|c|c|c|c|c|c|c|}
\hline World country & Asia & NAFTA & $\begin{array}{c}\text { Rest of } \\
\text { UE }\end{array}$ & $\begin{array}{c}\text { Latin } \\
\text { America }\end{array}$ & $\begin{array}{l}\text { Africa \& } \\
\text { Oceania }\end{array}$ & EU & $\begin{array}{l}\text { World } \\
\text { country }\end{array}$ & Asia & NAFTA & $\begin{array}{c}\text { Rest of } \\
\text { UE }\end{array}$ & $\begin{array}{c}\text { Latin } \\
\text { America }\end{array}$ & $\begin{array}{l}\text { Africa \& } \\
\text { Oceania }\end{array}$ & EU \\
\hline Import \%share & $37 \%$ & $11 \%$ & $6 \%$ & $5 \%$ & $4 \%$ & $37 \%$ & $\begin{array}{l}\text { Export \% } \\
\text { share }\end{array}$ & $33 \%$ & $14 \%$ & $5 \%$ & $2 \%$ & $2 \%$ & $44 \%$ \\
\hline
\end{tabular}

Table 9: Global chemical import and export percentage shares (2010) [37].

\begin{tabular}{|l|c|c|c|c|c|c|c|c|}
\hline Year & Total sales in (billion \$) & China & Europe (EU) & Rest of Asia & North America & Japan & South America & Rest of World \\
\hline $\mathbf{2 0 0 1}$ & 1829 & 8.1 & 29.8 & 14.0 & 27.6 & 10.7 & 4.5 \\
\hline $\mathbf{2 0 1 1}$ & 3567 & 26.8 & 19.6 & 18.8 & 17.1 & 6.4 & 5.5 \\
\hline
\end{tabular}

Table 10: The geographic breakdown (\%) of the worldwide chemical sales in 2001 and 2011 [37].

\begin{tabular}{|c|c|c|c|c|c|c|c|c|c|}
\hline Year & 2004 & 2005 & 2006 & 2007 & 2008 & 2009 & 2010 & 2011 & Average (2005-2011) \\
\hline USD million & 321.64 & 398.61 & 477.99 & 572.79 & 803.94 & 966.58 & 832.07 & 830.79 & 650.54 \\
\hline$\%$ Growth & - & $23.93 \%$ & $219.92 \%$ & $19.83 \%$ & $40.36 \%$ & $20.23 \%$ & $-3.92 \%$ & $-0.16 \%$ & $15.74 \%$ \\
\hline
\end{tabular}

Table 11: Ethiopian Chemical and Chemical Products Import Value: USD Million (2004-2011) [30,33]. 
Citation: Jilcha K, Kitaw D (2015) Lean Philosophy for Global Competitiveness in Ethiopia Chemical Industries: Review. J Comput Sci Syst Biol 8: 304-321. doi:10.4172/jcsb.1000205

\begin{tabular}{|c|c|c|c|}
\hline S No & Types of chemical imported & Average CIF value in Million USD & Average percentage growth \\
\hline $\mathbf{1}$ & Basic Chemicals & 337.5 & $20 \%$ \\
\hline $\mathbf{2}$ & Pharmaceutical & 66 & $22 \%$ \\
\hline $\mathbf{3}$ & Other Chemical Products & 48 & $14 \%$ \\
\hline $\mathbf{4}$ & Soap, Surface active agents & 23 & $15 \%$ \\
\hline $\mathbf{5}$ & Tanning and Dyeing extracts & 675 & $15 \%$ \\
\hline
\end{tabular}

Table 12: Major imported chemical and chemical products 2005-2011 [30,33].

\begin{tabular}{|c|c|c|c|c|c|c|c|c|c|c|c|}
\hline Importer & 2004 & 2005 & 2006 & 2007 & 2008 & 2009 & 2010 & 2011 & Ave. & Average $\%$ growth & $\%$ share of Ethiopia \\
\hline World & 838 & 940 & 1044 & 1232 & 1429 & 1243 & 1432 & 1649 & 1226 & $10.64 \%$ & $0.05 \%$ \\
\hline Africa & 15.11 & 16.85 & 20.97 & 25.18 & 35.06 & 32.44 & 37.32 & 42.51 & 28.18 & $16.68 \%$ & $2.3 \%$ \\
\hline COMESA & 3.54 & 3.85 & 4.41 & 4.49 & 10.61 & 10.50 & 11.62 & 12.84 & 7.73 & $25.91 \%$ & $8.4 \%$ \\
\hline Ethiopia & 0.32 & 0.40 & 0.48 & 0.57 & 0.80 & 0.97 & 0.83 & 0.83 & 0.65 & $15.74 \%$ & -- \\
\hline
\end{tabular}

Table 13: Import value of chemical and chemical products: USD Billion and growth rate [37].

during the same period the import of Africa grew with an average rate of $16.68 \%$ to reach 42.51 Billion USD, while the import of COMESA and Ethiopia grew at an average rate of $25.91 \%$ and $15.74 \%$ to reach 12.84 and 0.83 Billion USD respectively. As compared to the global import Share of Ethiopia is $0.05 \%$ which is negligible. If the import of chemical and chemical products to Ethiopia continues with the same average rate of $15.74 \%$ until 2025 the country will spend 3.33 billion USD and 6.99 billion USD for import of Chemical and chemical products by 2020 and 2025 respectively. So it is important to work in the chemical sector to substitute the imported products, in addition to this there is also an ample market in the Common Market for Eastern and Southern Africa (COMESA) member state for chemical and chemical products. As the average import value of COMESA member countries during 2004-2011 was 7.73 Billion USD and it is expected to grow at an average growth rate of $25.91 \%$.

Diversification area of the chemical industry sector in Ethiopia: Ethiopia is endowed with mineral agricultural and energy resources for the development of the chemical industry sector. In order to diversify the chemical sector it is possible to consider two approaches.

1. Based on the consumption of local demand of the industry, agriculture and service sectors and resources potentials.

If the country is going to be a middle income economy by 2025 the manufacturing sector and other sector should have to grow at faster rate. By considering that the industry, agriculture and service sector grows at faster rate to attain the 2025 target, the following will be area of diversification for the chemical industry. Chemicals used in: textile and Leather products manufacturing, metal and engineering products manufacturing, electronics and automotive products manufacturing, agro processing sector, pulp and paper products manufacturing, agricultural sector and construction sector.

2. Based on the resource potentials and the domestic and regional (COMEASA) market. It is possible to diversify the chemical sector in the area like:

- Base chemicals: organic chemicals, inorganic chemicals, fertilizer and bio based chemicals / petro chemicals

- Specialty chemicals: dyes and pigments, leather chemicals, construction chemicals, personal care ingredients, food additives and industrial gases.

- Knowledge chemicals: agro chemical, pharmaceutical and Biotechnology.
- Since Cement and none metallic constriction input materials like glass and ceramic are currently considered as a sub sector in the chemical industry of Ethiopia there is a potential of: lime based industries, Cement, Ceramic, tiles and gypsum board and Glass

Depending on the above analysis of diversification of Ethiopian chemical industries product categories considered by MoI, we could have detailed categories as shown in the table. Chemical and chemical product related industries obtained from CSA, 2013/14 and MoI, CIDI data categories (Table 14) [33,39,40].

Industrial development in Ethiopia is reported is in its infant stage but the government one of the strategies is to attract investors and establish small, medium and large manufacturing industries. As a result of this industrial development weakness, the chemical industries are also not developed well yet. Chemical industries are contributing less to the economy of the country because they are not able to export products to gain foreign currency. But the industrial sector development plan are well organized and established as chemical and construction material industry development institute and food, beverage and pharmaceutical industry development institutes under the Ministry of Industry. The weakness of industrial sectors emanate from the various factors.

Ethiopian chemical competitiveness and performance indicator parameters: The development of any industries in Ethiopia is at infant stage so that the small industrial sectors exist are contributing less to the economic development. Among these industrial sectors one is chemical industry which contributes for the development of economy. Of course, the chemical industries investment scenario is found in pre-implementation stage, implementation stage and operational stage since 1992 [30]. It created job opportunity for permanent and temporary employment of 39,620 and 41,520 citizens respectively in all small, medium and large manufacturing industries. This chemical investment activity includes more than 728 investors manufacturing different types of chemical products. This all chemical manufacturing industries are running almost in all region of the country. Industrial sectors also contributed for the GDP of the country about $13.6 \%$ of the economy in 2011/12.

A) Employment trend in chemical industries: Population growth is the other factor that influences the market demand of the chemical sector considering the knowledge, specialty and commodity chemicals in particular. On top of this the population growth adds up to the availability of young and relatively low cost labor in giving advantage to the chemical industry shift. In spite of the fact that there are less stringent environmental laws in other countries compared to the 
Citation: Jilcha K, Kitaw D (2015) Lean Philosophy for Global Competitiveness in Ethiopia Chemical Industries: Review. J Comput Sci Syst Biol 8: 304-321. doi:10.4172/jcsb. 1000205

eastern world still the shift of chemical industries can be influenced by environmental protection issues.

Industries one parameter of competitiveness indicator is employment scenario. Here in Ethiopia chemical industries are creating employment opportunity for the citizen year after year increasingly. Table 15 shows that the chemical industry contribution to employment beginning from 2000 to 2004 E.C.

Manufacturing of non- metallic mineral chemical products are contributing high employment rate and increasing over years. The second manufacturing of chemical industry is rubber and plastic increasingly creating employment opportunity and manufacturing of chemical and their products and paper and paper products are contributing less than 20,000 employments over the periods. The chemical sector employment shows an annual average growth of $8.52 \%$. The chemical industrial sectors contribution to the employment reached about 57,064 in 2011/12 that is an indication of its contribution to the development of economy.

B) New chemical industries established: Chemical industries establishment is one of the indication of chemical industry development and focus area to the industries. The chemical industries established from 2000 to 2004 E.C was recorded as total of 4,129 medium and large scale manufacturing industries. The following figure indicates the number of each new chemical industry established in each year. It is somewhat fluctuating year after year but in general its establishment seems constant over the five years indicated in Figure 4.

\begin{tabular}{|c|c|}
\hline $\begin{array}{l}\text { Chemical manufacturing } \\
\text { industries }\end{array}$ & $\begin{array}{l}\text { Types of chemical products under each } \\
\text { manufacturing industries }\end{array}$ \\
\hline \multirow[t]{5}{*}{$\begin{array}{l}\text { Manufacture of Chemicals } \\
\text { and Chemical Products }\end{array}$} & $\begin{array}{l}\text { Manufacture of basic chemicals, except } \\
\text { fertilizers and nitrogen compounds }\end{array}$ \\
\hline & Manufacture of paints, varnishes and mastics. \\
\hline & $\begin{array}{l}\text { Manufacture of pharmaceuticals, medicinal } \\
\text { chemicals and botanical products }\end{array}$ \\
\hline & $\begin{array}{l}\text { Manufacture of soap and detergents cleaning } \\
\text { and polishing, perfumes and toilet preparations }\end{array}$ \\
\hline & Manufacture of chemical products nec ${ }^{1}$ \\
\hline \multirow{2}{*}{$\begin{array}{l}\text { Manufacture of Rubber and } \\
\text { Plastic Products }\end{array}$} & Manufacture of rubber products \\
\hline & Manufacture of plastic products \\
\hline \multirow{2}{*}{$\begin{array}{l}\text { Manufacture of Paper, Paper } \\
\text { Products and Printing }\end{array}$} & Paper and paper products \\
\hline & Publishing and printing services \\
\hline \multirow{5}{*}{$\begin{array}{l}\text { Manufacture of Other Non- } \\
\text { Metallic Mineral Products }\end{array}$} & Manufacture of glass and glass products \\
\hline & Manufacture of structural clay products \\
\hline & Manufacture of cement, lime and plaster \\
\hline & $\begin{array}{c}\text { Manufacture of articles of concrete, cement anc } \\
\text { plaster }\end{array}$ \\
\hline & $\begin{array}{l}\text { Manufacture of non-metallic mineral products } \\
\qquad n \mathrm{c}^{1}\end{array}$ \\
\hline
\end{tabular}

nec $=$ Not elsewhere classified

Table 14: Chemical and chemical products related manufacturing industries in Ethiopia [33,39,40].

\begin{tabular}{|l|l|l|l|l|l|}
\hline Industrial group & $\mathbf{2 0 0 0}$ & $\mathbf{2 0 0 1}$ & $\mathbf{2 0 0 2}$ & $\mathbf{2 0 0 3}$ & $\mathbf{2 0 0 4}$ \\
\hline $\begin{array}{l}\text { Manufacture of Chemicals and } \\
\text { Chemical Products }\end{array}$ & 8,917 & 8,822 & 9,998 & 10,076 & 9,013 \\
\hline $\begin{array}{l}\text { Manufacture of Rubber and Plastic } \\
\text { Products }\end{array}$ & 7,762 & 8,031 & 11,185 & 9,744 & 11,028 \\
\hline $\begin{array}{l}\text { Manufacture of Paper, Paper } \\
\text { Products and Printing }\end{array}$ & 8,727 & 11,958 & 13,859 & 10,984 & 12,745 \\
\hline $\begin{array}{l}\text { Manufacture of Other Non-Metallic } \\
\text { Mineral Products }\end{array}$ & 16,853 & 19,790 & 19,482 & 17,230 & 24,278 \\
\hline Total & 42,259 & 48,601 & 54,524 & 48,034 & 57,064 \\
\hline
\end{tabular}

Table 15: Employment trend in chemical industries [40].
C) Gross value of production of chemical industries: The gross value of the chemical manufacturing industry in 2011/12 is higher than the others. The amount registered in the CSA was 25,685,176 ETB as shown in Figure 5. The gross value of production is an indication of chemical industries contribution to the economy. However, the GDP share is very small.

D) Value added in chemical industries production: The percentage distribution of value added, which indicates the contribution level of Large and Medium scale, manufacturing industries, to the total value added in the manufacturing sector, by industrial groups is given in Figure 4 for the period 2000-20004 E.F.Y. The data in this figure makes obvious, the fact that, increasing in distribution of value added contribution to the value added, was significantly higher than the other chemical industrial groups, thought out the period under review. As the Figure 6 indicates the value adding of the chemical industries are

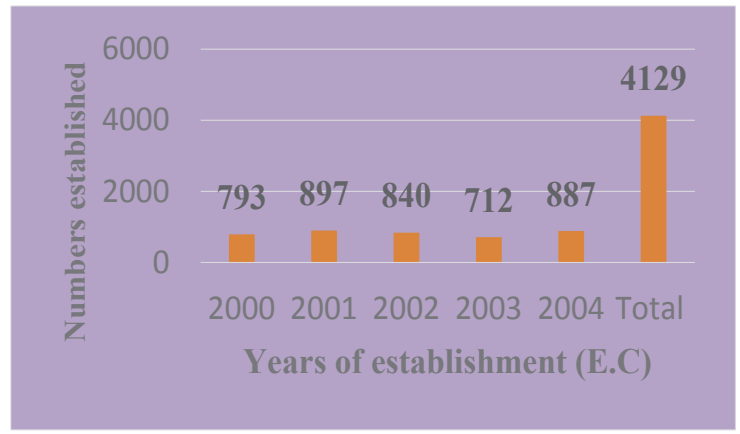

Figure 4: Number of chemical Industries newly established (2006/072011/12) [40].

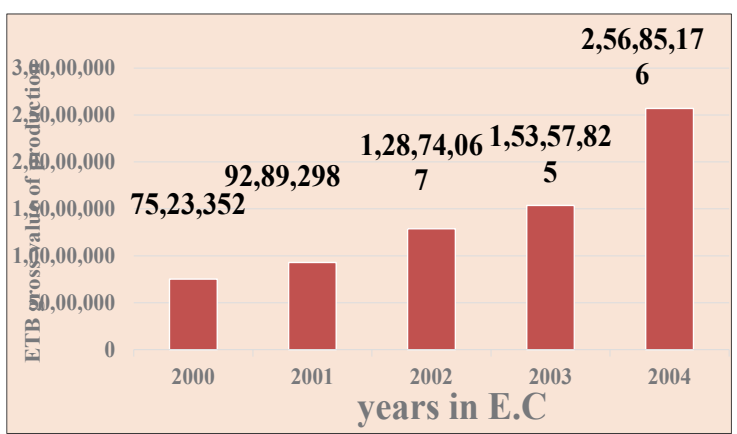

Figure 5: Gross Value of Production of Chemical Industries (2006/072011/12) [40].

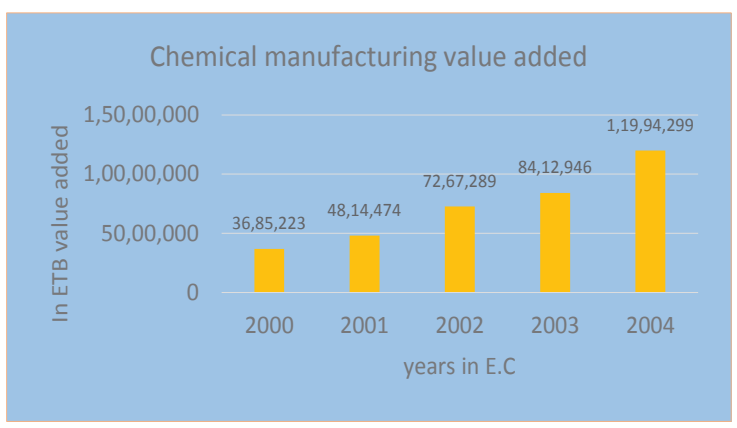

Figure 6: Chemical Industries Value added (2006/07-2011/12) [40]. 
in increasing trend. The chemical industries are value adding yearly in average of 7,234,846 ETB. In 2004 E.C the value added was 11,994,299 ETB which is higher than the previous year by $3.581,353$ ETB that means increment of $42 \%$ [ 41 ].

Manufacturing of non-metallic mineral and other chemical products take the maximum share of the value added products. In the second place the chemical and chemical products has got the higher value addition to the production process. So, among the four segments, the non-metallic mineral products manufacturing are highly contributing in value addition. The value added chemicals percentage share of each was $(4.94 \%)$ paper, paper products and printing, $(8.1 \%)$ Manufacture of chemicals and chemical products, (5.74\%) Manufacture of rubber and plastic products and (19.15\%) Manufacture of other nonmetallic mineral products.

E) Ratio of imported raw material to consumed raw material costs of chemicals: Table 16 shows that the ratio of imported raw material to consumed total raw material for chemical products manufacturing. Each year the imported raw material consumption is almost average to $66 \%$ and the rest of the raw material are wasted. In the view of lean manufacturing this is an indication that lean manufacturing principles and philosophy left behind. In general the lean chemicals principles still yet even as it was described by other literatures. Here it is true that the cost of raw materials imported which is not consumed is $44 \%$ as any waste.

F) Ratio of cost of energy consumed to total industrial cost: In the present scenario the driving force the future strategies of the chemical sector are focusing on three mega trends. The three mega trends that are supposed to influence the chemical sector are energy, environmental protection and growth of population.

The nature of most chemical industries is mainly related with their energy intensive application. Recently, the cost of energy is becoming one of the cost factors significantly affecting the competitiveness of the chemical industry. Because of these facts the options at hand is either working towards energy efficiency for optimum energy consumption or search for cheap energy shifting to countries applying cheap energy sources. This is an indication by which lean application that has not been exercised in energy considered in chemical industries. The chemical manufacturing industry ratio of cost of energy consumed to total industrial cost by major industrial groups for the period 2000-2004 E.F.Y. is presented in Table 17. The figures in this table indicate that, non-metallic mineral products manufacturing recorded the highest proportion of cost of energy consumed to the total industrial cost, throughout the period under review, exhibiting bout $53.3 \%$ in average. The energy consumption in 2001 was highest as $62.1 \%$, there after the energy consumption of the chemical industries were decreased. When the cost of energy compared to the whole industrial sectors, the highest energy cost consumption was also recorded under that nonmetallic

\begin{tabular}{|l|l|l|l|l|l|l|}
\hline S No & Chemical industries & $\mathbf{2 0 0 0}$ & $\mathbf{2 0 0 1}$ & $\mathbf{2 0 0 2}$ & $\mathbf{2 0 0 3}$ & $\mathbf{2 0 0 4}$ \\
\hline $\mathbf{1}$ & $\begin{array}{l}\text { Manufacture of paper, paper } \\
\text { products and printing }\end{array}$ & $81.5 \%$ & $73.7 \%$ & $59.5 \%$ & $73.3 \%$ & $58.4 \%$ \\
\hline $\mathbf{2}$ & $\begin{array}{l}\text { Manufacture of chemicals and } \\
\text { chemical products }\end{array}$ & $87.1 \%$ & $79.9 \%$ & $70.5 \%$ & $74.9 \%$ & $82.3 \%$ \\
\hline $\mathbf{3}$ & $\begin{array}{l}\text { Manufacture of rubber and plastic } \\
\text { products }\end{array}$ & $77.2 \%$ & $95.0 \%$ & $92.3 \%$ & $93.0 \%$ & $87.0 \%$ \\
\hline $\mathbf{4}$ & $\begin{array}{l}\text { Manufacture of other non-metallic } \\
\text { mineral products }\end{array}$ & $19.8 \%$ & $18.6 \%$ & $58.1 \%$ & $25.5 \%$ & $29.7 \%$ \\
\hline $\mathbf{5}$ & $\begin{array}{l}\text { Average import to consumed raw } \\
\text { materials costs }\end{array}$ & $66.4 \%$ & $66.8 \%$ & $70.1 \%$ & $66.7 \%$ & $64.4 \%$ \\
\hline
\end{tabular}

mineral productions. This large proportion was mainly due to the high energy requirement by cement and glass and glass products manufacturing establishments.

Lean energy: Over the years, many global manufacturers have secured big gains in labor and capital productivity by applying the principles of lean manufacturing. Fewer companies, however, have applied lean know-how to energy productivity. Line workers and even senior managers often consider energy is given when they consider it at all. The waste of energy and resources is typically overlooked or excluded from lean problem solving on the grounds that it is too complex for the front line to address, cuts across too many functions, or both [42]. Here lean thinking for the loss of energy has not been yet considered in chemical manufacturing industries.

G) Ratio of cost of labor to value added: Cost incurred more in manufacturing of papers, papers productions and printing relative to the value added as $32 \%$ which means out of 100 products value added 32 birr was costs for labor. The second stage of manufacturing of chemical is rubber and plastic production costing more labor. Manufacturing of other non-metallic minerals production comparatively costs less and more value added (Table 18).

H) Ratio of operating surplus to gross of production: This is the company profitability indication parameter and its competitiveness situation. The surplus obtained from the gross production is high in average in case of $35 \%$ from the nonmetallic mineral and other chemical products.

The ratio of operating surplus to gross value of production by major chemical industrial categories combined is presented in Table 19. The share of all four major chemical industrial groups and the overall average exhibited a decrease in 2004 E.F.Y against 2001, 2002 and 2003 E.F.Y.

Chemical industry challenges in Ethiopia: The industrial development scenario is at infant stage currently as a whole compared with the other services and agricultural activities. Since the industrial development in our country is perishing at the ground, the chemical manufacturing industries development challenges get

\begin{tabular}{|l|l|l|l|l|l|l|c|}
\hline $\begin{array}{l}\text { S } \\
\text { No }\end{array}$ & Chemical industries & $\mathbf{2 0 0 0}$ & $\mathbf{2 0 0 1}$ & $\mathbf{2 0 0 2}$ & $\mathbf{2 0 0 3}$ & $\mathbf{2 0 0 4}$ & Average \\
\hline $\mathbf{1}$ & $\begin{array}{l}\text { Manufacture of paper, } \\
\text { paper products and printing }\end{array}$ & $5.2 \%$ & $6.0 \%$ & $3.5 \%$ & $3.0 \%$ & $4.3 \%$ & $4.4 \%$ \\
\hline $\mathbf{2}$ & $\begin{array}{l}\text { Manufacture of Chemicals } \\
\text { and Chemical Products }\end{array}$ & $3.1 \%$ & $2.6 \%$ & $2.6 \%$ & $2.4 \%$ & $1.7 \%$ & $2.5 \%$ \\
\hline $\mathbf{3}$ & $\begin{array}{l}\text { Manufacture of Rubber and } \\
\text { Plastic Products }\end{array}$ & $3.8 \%$ & $5.9 \%$ & $4.7 \%$ & $5.4 \%$ & $4.1 \%$ & $4.8 \%$ \\
\hline $\mathbf{4}$ & $\begin{array}{l}\text { Manufacture of other non- } \\
\text { metallic mineral products }\end{array}$ & $57.2 \%$ & $62.1 \%$ & $57.2 \%$ & $43.0 \%$ & $47.2 \%$ & $53.3 \%$ \\
\hline & Total & 0.693 & 0.766 & 0.68 & 0.538 & 0.573 & $65.0 \%$ \\
\hline
\end{tabular}

Table 17: Ratio of cost of energy consumed to the total industrial costs [40].

\begin{tabular}{|l|l|l|l|l|l|l|l|}
\hline $\begin{array}{l}\text { S } \\
\text { No }\end{array}$ & Chemical industries & $\mathbf{2 0 0 0}$ & $\mathbf{2 0 0 1}$ & $\mathbf{2 0 0 2}$ & $\mathbf{2 0 0 3}$ & $\mathbf{2 0 0 4}$ & Average \\
\hline $\mathbf{1}$ & $\begin{array}{l}\text { Manufacture of Paper, Paper } \\
\text { Products and Printing }\end{array}$ & $43 \%$ & $32 \%$ & $29 \%$ & $23 \%$ & $31 \%$ & $32 \%$ \\
\hline $\mathbf{2}$ & $\begin{array}{l}\text { Manufacture of Chemicals and } \\
\text { Chemical Products }\end{array}$ & $30 \%$ & $16 \%$ & $20 \%$ & $15 \%$ & $19 \%$ & $20 \%$ \\
\hline $\mathbf{3}$ & $\begin{array}{l}\text { Manufacture of Rubber and } \\
\text { Plastic Products }\end{array}$ & $30 \%$ & $27 \%$ & $22 \%$ & $22 \%$ & $23 \%$ & $25 \%$ \\
\hline $\mathbf{4}$ & $\begin{array}{l}\text { Manufacture of other Non- } \\
\text { Metallic Mineral Products }\end{array}$ & $17 \%$ & $19 \%$ & $11 \%$ & $13 \%$ & $15 \%$ & $15 \%$ \\
\hline
\end{tabular}

Table 18: Ratio of cost of labor to value added chemicals [40]. 


\begin{tabular}{|c|c|c|c|c|c|c|c|}
\hline $\begin{array}{c}\text { S } \\
\text { No }\end{array}$ & $\begin{array}{c}\text { Chemical Manufacturing } \\
\text { Industries }\end{array}$ & $\mathbf{2 0 0 0}$ & $\mathbf{2 0 0 1}$ & $\mathbf{2 0 0 2}$ & $\mathbf{2 0 0 3}$ & $\mathbf{2 0 0 4}$ & Average \\
\hline 1 & $\begin{array}{c}\text { Manufacture of Paper, Paper } \\
\text { Products and Printing }\end{array}$ & $15 \%$ & $23 \%$ & $23 \%$ & $24 \%$ & $17 \%$ & $20 \%$ \\
\hline 2 & $\begin{array}{c}\text { Manufacture of Chemicals and } \\
\text { Chemical Products }\end{array}$ & $14 \%$ & $22 \%$ & $20 \%$ & $25 \%$ & $17 \%$ & $20 \%$ \\
\hline 3 & $\begin{array}{c}\text { Manufacture of Rubber and } \\
\text { Plastic Products }\end{array}$ & $12 \%$ & $18 \%$ & $21 \%$ & $19 \%$ & $15 \%$ & $17 \%$ \\
\hline 4 & $\begin{array}{c}\text { Manufacture of other Non- } \\
\text { Metallic Mineral Products }\end{array}$ & $37 \%$ & $29 \%$ & $45 \%$ & $33 \%$ & $29 \%$ & $35 \%$ \\
\hline
\end{tabular}

Table 19: Ratio Operating Surplus to Gross Value of Production [40].

high. The chemical industry challenges arise due to so many factors. The adoptions of new technology to the economy are very hard and require high economic development. As a result of not utilizing high technology the chemical manufacturing industries stay at infant stage. The other one is the management commitment to eliminate any waste of companies i.e., implementing the lean principles in the initial flourishing industries. The chemical development also requires huge professionals and devotion to the production activity with standing chemical health and safety challenges. The environmental profile is also the factor that influences chemical industries establishments.

With respect to the globally competitive chemical industries, it can in general be concluded that Ethiopia is uncompetitive through the chemical industry (i.e., there are no well-equipped chemical industries). The basic reason for such conclusion is that there are no any basic chemical manufacturing industries (such as petrochemicals, polymers, etc.) in the country. Even these industries which are being considered as chemical manufacturers (such as soap and detergent manufacturers, pharmaceuticals, plastic, paint producers, and etc.) use outdated technologies, lack skilled manpower, and related financial problems; and these were given less due consideration as that of the other sectors (Leather, Textile, agro-industry, etc.). The basically known chemical industries are those which consume basic chemicals and process to give another form of chemical end products which might include: soap and detergent firms, pulp and paper product manufacturers, pharmaceuticals, and etc. All these huge sectors of investment are simply aggregated to be under the supervision of the chemical industry development office of the ministry of industry since they are too weak both in infrastructural capability and economically. Moreover, their unavailability and unavailability of other sectors to consume their outputs makes the sectors to be neglected (Table 20).

Application of lean in chemicals industries: Lean has been defined as the waste management and customer value principle and philosophy of any manufacturing industries. In the chemical industries exist in Ethiopia there is no lean application as it has been defined in their production, value adding scenario, cost minimization and customer satisfaction records output being small. Most of the chemical products are import products for the customers. As a result of this all chemical products users are not satisfied by the imports products because of high cost of the products, long delivery time/ due date/, and shortage of supplies to some product producing companies.

Process manufacturing is fundamentally different from discrete manufacturing in the way material flows. Material flows in a continuous stream in process manufacturing, while parts move in discrete batches in discrete. Since there has been so much work done in developing these methodologies in discrete manufacturing and very little in process, it might seem logical to apply them "as-is" to process-manufacturing industries. However, this approach is like trying to fit square pegs into round holes. The better approach is to adapt these techniques within

\begin{tabular}{|l|l|}
\hline Strength/potentials & Weakness/problems \\
\hline Investment incentive policy & No utilization of technological equipment \\
\hline Educational supply & Inability of Product diversification \\
\hline Industrial development strength & $\begin{array}{l}\text { Improper productivity improvement tools } \\
\text { implementation }\end{array}$ \\
\hline Strong local market potential & $\begin{array}{l}\text { Relatively small scale by international } \\
\text { standards }\end{array}$ \\
\hline $\begin{array}{l}\text { Guiding national policies and } \\
\text { strategies }\end{array}$ & $\begin{array}{l}\text { Insufficient hazardous waste processing } \\
\text { facilities }\end{array}$ \\
\hline $\begin{array}{l}\text { Young and talented workforce } \\
\text { upcoming }\end{array}$ & Less awareness on R\&D \\
\hline Ethiopia's geostrategic importance & Lack of budget \\
\hline $\begin{array}{l}\text { Availability of precious raw materials } \\
\text { (soda ash, essential walls, coal, etc.) }\end{array}$ & $\begin{array}{l}\text { Lack of chemical consuming industrial } \\
\text { sectors }\end{array}$ \\
\hline Opportunity/promises & Threat/pressures \\
\hline Human resource availability & $\begin{array}{l}\text { High chemical producing companies } \\
\text { competition }\end{array}$ \\
\hline $\begin{array}{l}\text { Government focus on investment } \\
\text { policy }\end{array}$ & Shortage of raw matter inputs [resources] \\
\hline Geographical setup & Chemical environmental pollution \\
\hline Peace and security & Employee health problem \\
\hline $\begin{array}{l}\text { Abundant water \& other natural } \\
\text { resource }\end{array}$ & Fluctuating market prices \\
\hline Abundant hydroelectric power & High cost of technology \\
\hline $\begin{array}{l}\text { Increasing investments in private } \\
\text { sector }\end{array}$ & Shortage of financial aids and budget \\
\hline $\begin{array}{l}\text { Better trade ties with different } \\
\text { countries }\end{array}$ & ing \\
\hline
\end{tabular}

Table 20: SWOT analysis of chemical industries.

a process improvement framework that identifies the various forms of waste in the process-manufacturing value stream, and manages the wastes with the appropriate concepts and tools $[42,43]$.

Every industry implemented ISO and even QMS [Kaizen]. Companies on implementation of Kaizen and its elements are: Chemical Industries: Awash Tannery, Abyssinia Tannery, Pharmaceuticals: Addis Pharmaceuticals Cement: Mugher Cement Factory, Paint: Cadisco Paint Factory, Paper and Pulp: Yekatit Paper Converting Factory.

Practice of lean in Ethiopia plastic industry: A case study: Ethiopia Plastic Industry is Government owned public Industry which had been initially established by five Italian private entrepreneurs in 1960 E.C and in 1978 E.C. the Government was fully owned the company. Since 2003 E.C the Industry was transferred and continued its operation under Metals and Engineering Corporation. It has continued the Production and Sales of Plastic Products Under the Supervision of Chemical Corporation [40]. In Ethiopia Plastic Industry, there are four factories: Wire and Cable factory, pipe factory, Injection blow molding and Poly and printing factory. The company has stated quality policy properly so that top management will be aware of quality. This is an excellent initiative for the factory to have quality department.

Ethiopia plastic Industry has good staff composition from detail of human resource data records, but it lacks Industrial and mechanical engineers among 413 employees which has impact and influence on the quality of products design and control directly or indirectly. This considered because one Polymers are the largest revenue segment at about $33 \%$ of the basic chemicals dollar value, includes all categories of plastics and man-made fibers throughout the globe, Second the major markets for plastics are increasing and widely used in the society instead of metals and wood products. Thirdly Ethiopia has many plastic companies as small, medium and large as 2128 [30] and the medium and large plastic industries of 335 [CSA, 2013]. So, in Ethiopia the plastics 
Citation: Jilcha K, Kitaw D (2015) Lean Philosophy for Global Competitiveness in Ethiopia Chemical Industries: Review. J Comput Sci Syst Biol 8: 304-321. doi:10.4172/jcsb. 1000205

sector has been one of the better performing sectors in recent years in terms of output and employment. Plastic products are increasingly replacing metal products, thus placing the plastics sector at the core of manufacturing. The major market share EPI is pipe factory $(43 \%)$ and the second is poly factory (33\%) share from its 9 month of sales of 2013/14.

EPI is considered as representative chemical industry to analyses the lean principles and its competitiveness strategy in relation with the review literature.

The plastic industry has faced the problems emanating from the different factors in the industrial sector. The problems identified during the survey of the industry were raw material shortage, electric power interruption, measurement problems, operators negligence and error, machine utilized outdated and method of work. The organized way operation and waste minimization technique did not give opportunity to the EPI to implement properly the lean philosophy.

As the Figure 4 of cause and effect diagram indicated that the company is underutilizing it all resources. The lean principles and philosophy were not introduced to the company. The company management has no lean idea and no implementation procedure set. The company thinking to adopt Kaize one of the lean tool but this may not fully minimize the waste of the company. The company wasting time, incapable of utilizing the human resources properly, going over production of unnecessary product or under production of necessary requirements. The supply chain management of the company leads it to fail in out of production and results in delay of customers demand in time. Inventory management problem and warehousing problems for the raw materials and finished products.

The company increasing the labor cost, electric energy loss and unnecessary costs investment on the unnecessary operation in the company. The company has incurred also labor force waste due to the electric interruption, outdated machinery maintenance, reworks, health problem due to unsafe work place, and waste of time due to machinery maintenances.

Benefit of being lean was considered as one of the improvement tool for saving finance in chemical industries and related products or process industries. But in this case, company it is dared that lean thinking is not exist. As a result of these the company is not using the benefit of lean in saving finance and even no one who accept the lean principle. The company thinks that they are working right and well $[8,9,11]$ (Figure 7).

The company has also increased lead time for raw material since it is imported from the foreign suppliers. As a result of this the customer's complaints happened. This reduces the customer's value and final leads customers to switch off for the company product and find other producers or suppliers. The case company also increases the rework even though the lean principle is to reduce rework in process industries. The EPI incurs cost of a rework of flexible conduit only to 5400 ETB in month. This is waste of money, energy, labor force and time.

In general the companies letting ignore the principle of lean thinking to the company. They consider that to apply lean is perceived lack of tangible benefits and the view of much business process are already efficient.

\section{Challenges of Case Company Being Not Lean}

Top management commitment is weak to take smooth flow of material, value customers (internal customers), and loose decision making. The company has few workers and more or less unskilled professionals because the turnover is high due to management and employees conflict with top management. Shortage of resources; i.e., work forces and finances is highly experienced as it has been obtained from the company employees and some customer's responses. Special raw material supply is too weak to obtain it on the required time. The weaknesses of raw material supply caused the delay of customer orders and sometimes urge the company to respond no product which is an indication of not lean. The other challenge experienced in the company is unnecessary work flows and reworks to scrap elapsing more time, more energy, more finance, more labor forces, and other raw material resources. This is an indication of the company is not being lean. Unstable demand exercise the company due to supplies are from foreign more than $90 \%$ of it. These are because the company has weak linkage with the suppliers to deliver it soon within the lead time.

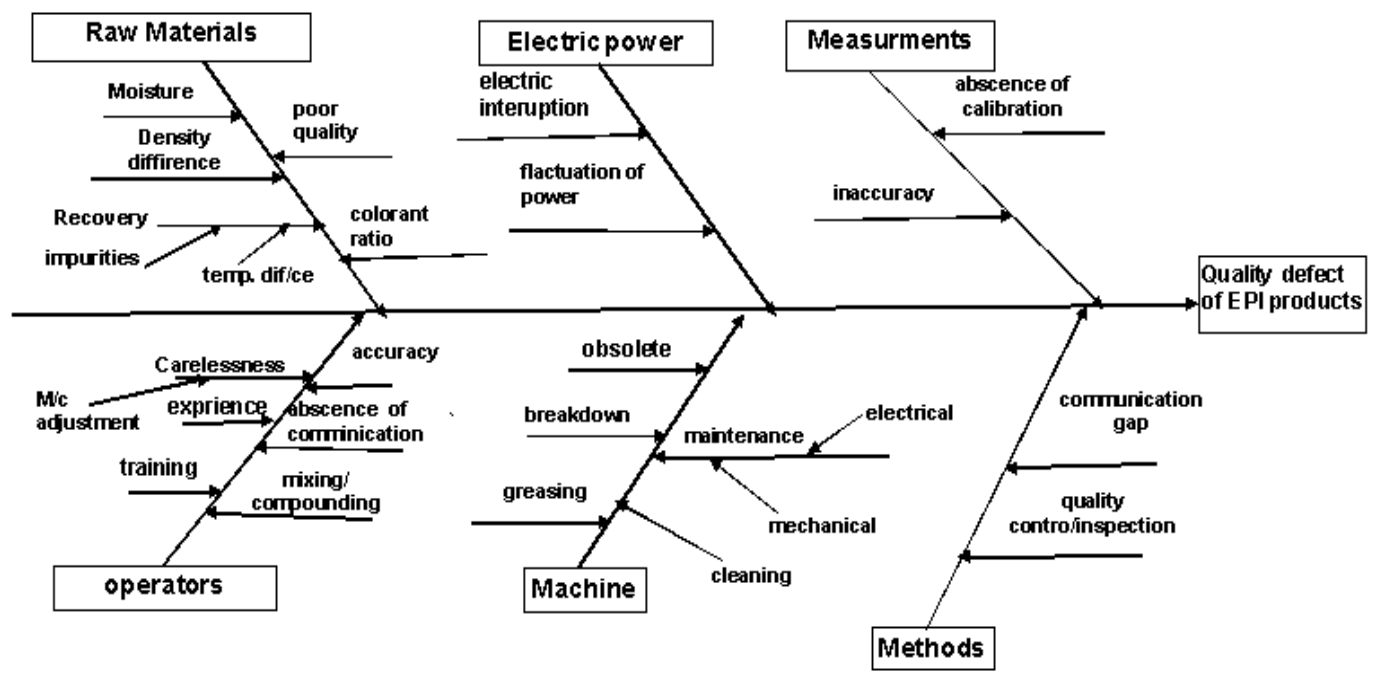

Figure 7: Ishikawa diagram for EPI. 


\section{Enactment of Lean in Ethiopia Plastic Industry}

The lean philosophy for any manufacturing industry has been explained in banning eight wastes. It helps in reducing non value adding activities and increasing the value adding activities in order to cut the costs of the company which arise unnecessarily. As it has been discussed in the literature part, there are many techniques and a benefit that improves the organization operations through continues implementation of lean philosophies.

Therefore, the lean philosophy is also key for the EPI production improvement and reduction of unnecessary activities and wastes. The company implementing the following lean techniques will change the current poor working systems and increasing the unnecessary activities/wastes (Figure 8) [36].

As Canvis, developed concepts of lean improvement, the EPI should also focus on customers first (internal and external), emphasize on people first, harmony with the environment, trust the workers, develop team work, focus on employ involvement, provide equal treatment to all people, make decision based on fact not on biased based, think for long term.

- Align the organization: this considers organizational structure change, integration of engineering floors, integration of finance, integration of quality, integration of human resources, integration of sales and marketing, integration of marketing, internal organization (developing reward and incentive system, effective utilization of skills, capability and resources) are lean changes to EPI.

- Organizational learning: consider building learning organization, manage innovation/knowledge and training lean EPI

- Design the lean change process: in leaning EPI, it is very essential to consider setting a Kaizen agenda under talking more researches and development to design new system and reduce barriers of the company.

- Translate strategy into objectives and lean initiatives: this can be achieved by Determine the nature of change, defining lean initiatives; Establishing lean performance parameters are some

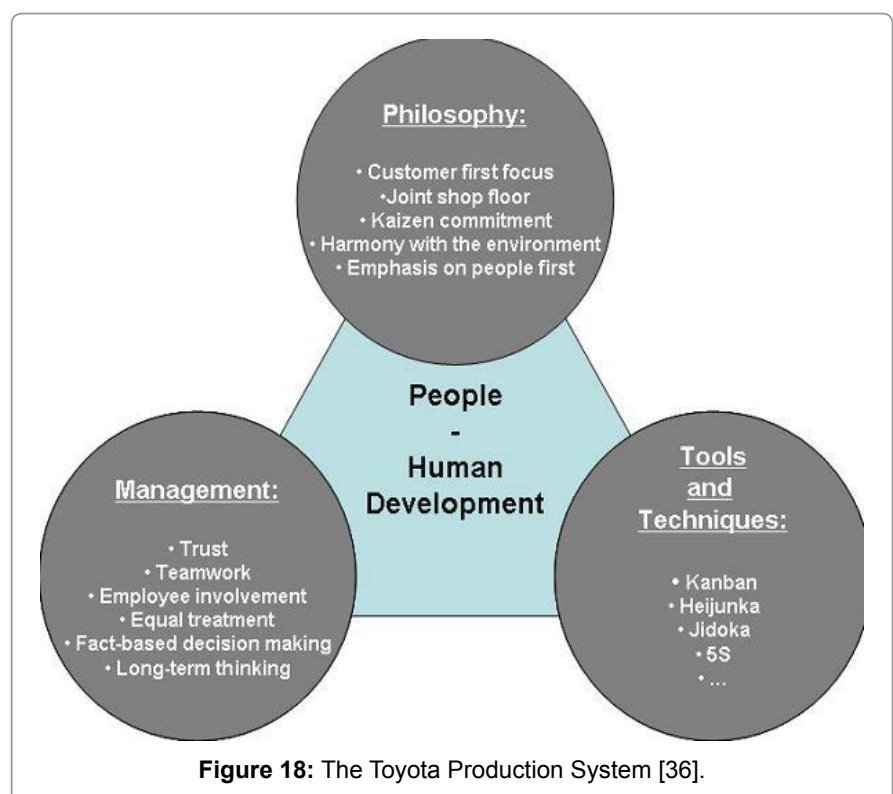

important points to translate the company current operation system to dynamic and radical changes.

Mobilize for lean change: it needs to EPI to see at the Stakeholder expectations, Lead the change by management bodies in motivating the large work forces, and maintain changes that change the traditional organization to Lean culture are very target points to the EPI.

In general the EPI should follow once it fulfills the above conditions to implement the following methods to bring lean change to it organization.

Lean manufacturing includes a set of principles that lean thinkers use to achieve improvements in productivity, quality, and lead-time by eliminating waste through kaizen. Kaizen is a Japanese word that essentially means "change for the better" or "good change" $[3,5,7,8,13]$. The goal is to provide the customer with a defect free product or service when it is needed and in the quantity it is needed. There are many tools and concepts that lean companies employ to support the above principles and eliminate waste. Here are 12 of the most critical one's for EPI to know and start right now targeting on $\mathrm{R}$ and $\mathrm{D}$ based activities:

- Cellular Manufacturing: it is an approach in which all equipment and workstations are arranged based on a group of different processes located in close proximity to manufacture a group of similar products. The primary purpose of cellular manufacturing is to reduce cycle time and inventories to meet market response times and EPI should look at it.

- Takt Time: This is the "heartbeat" of the customer. Takt time is the average rate at which a company must produce a product or execute transactions based on the customer's requirements and available working time. It considers Takt $=\mathrm{T} / \mathrm{D}, \mathrm{T}$ is Time available for product/service, $\mathrm{D}$ is a demand for the number of units and $\mathrm{T}$ gives information on production pace or units per hours.

- Standardized Work: A process of documented description of methods, materials, tools, and processing times required to meet takt time for any given job. This aids in standardizing the tasks throughout the value stream in EPI.

- One Piece Flow or Continuous Flow: This concept emphasizes reducing the batch size in order to eliminate system constraints. A methodology by which a product or information is produced by moving at a consistent pace from one value-added processing step to the next with no delays in between.

- Pull Systems and Kanban: A methodology by which a customer process signals a supplying process to produce a product or information or deliver product/information when it is needed. Kanban is the signals used within a pull system through scheduling combined with travelling instruction by simple visual devices like cards or containers in EPI.

- Five Why's: A thought process by which the question "why" is asked repeatedly to get to the root cause of a problem five times in the EPI.

- Heijunka / Leveling the Workload: The idea that, although customer order patterns may be quite variable, all of our processes should build consistent quantities of work over time (day to day, hour to hour). This strategy is adopted by intelligently planning different product mix, and its volumes over period of times.

- Total Productive Maintenance (TPM): A team-based system 
for improving Overall Equipment Effectiveness (OEE), which includes availability, performance, and quality. This aids in establishing a strategy for creating employee ownership autonomously for maintenance of equipment. The goal of the TPM program is to markedly increase production while at the same time increasing employee morale and job satisfaction. OEE (Overall Equipment Efficiency): $\mathrm{OEE}=\mathrm{A}^{\star} \mathrm{PE}^{\star} \mathrm{Q}$, where $\mathrm{A}$ - Availability of the machine. PE - Performance Efficiency. Q Refers to quality rate.

- Problem Solving / PDCA / PDSA: The PDCA cycle is a graphical and logical representation of how most individuals have already solved problems. It helps to think that every activity and job is part of a process, that each stage has a customer and that the improvement cycle will send a superior product or service to the final customer. PLAN: establish a plan to achieve a goal, DO: enact the plan, CHECK: measure and analyze the results and ACT: implement necessary reforms if results are not as expected. A system for identifying and solving problems to their root cause and then implementing counter measures with monitoring using ishikawa diagram.

The above tools and techniques to lean EPI are basic in taking detail studies on each tool and customize to the operation line.

\section{Ways Forward}

In line with lean application in chemical manufacturing industries, the lean principle introduction has been week in process industries in general globally. But as the studies stated lean manufacturing with possible application areas are very crucial like chemical industries. The chemical manufacturing like EPI and others which are running at small, scale and large enterprise getting more wastes regarding their whole operation in the industry.

It is clear that manufacturing industries development in Ethiopia is at initial stage. However, while any chemical industries developments are thought the country should equipped with lean principles. The application of lean and benefit is tested if only the industries are existings. Therefore, in line with lean philosophy any industries development should be first equipped with information or data. Thereafter they can develop value streaming process in reorganizing the process flow easily. The following forwards and tools should be customized to ban wastes of chemical manufacturing industries.

$\mathbf{R}$ and D: Although expensive and time-consuming, research and development is crucial to the industry's evolution. Research and development is the important are to know the market size, raw material size and resources for chemical companies near good centers of $\mathrm{R}$ and $\mathrm{D}$ within both the commercial and university sectors [26]. 5S Visual Workplace also creates a work environment that is clean, well-organized and efficient [34] by Sorting, Setting in Order, shining, standardizing and sustaining. Chemical manufacturing industries should follow Standardized Work Instructions (SWI's) that allow processes to be completed in a consistent, timely, and repeatable manner that employees will increase production, improve quality, and enjoy a safer, predictable working environment. Value Stream Mapping is also used to illustrate the flow and relationship between work processes. A key component of VSM is differentiating value adding activities from non-value adding activities. Reducing or eliminating non-value adding activities is of paramount importance and a principle goal of Lean Manufacturing. Total Productive Maintenance (TPM) is another powerful program for planning and achieving minimal machine downtime. Equipment and tools are literally put on "proactive" maintenance schedules to keep them running efficiently and with greatly reduced downtime. Maintenance technicians are liberated from mundane, routine maintenance, enabling them to focus on urgent repairs and proactive maintenance activities. "Kaizen Events" are highly focused improvement events designed to address and resolve important business issues and/or constraints. Error and Mistake Proofing known as "Poka Yoke" is one of the powerful Lean tools used to ensure products and processes are completed correctly the first time and companies should execute these operations. CI should focus on Self-Directed Work Teams, to a large degree, voluntarily interact with internal customers and suppliers to improve area effectiveness and effectively deal with area issues.

Mixed/Level-Loaded Production "Heijunka," provides a system for advanced scheduling of production activities. This lean tool allows reducing inventory, decreasing lead-times, and producing the variety of products customers want. Setup Reduction (S.M.E.D.) is single Minute Exchange of Die (SMED.), the Lean tool used to create very fast changeovers and setups that greatly reduce machine downtime and increase throughput. Inventory and Lead-time Reduction reduces excess inventory inherently presents a great deal of waste, not to mention quality issues (spoilage), storage requirements, investment of funds, limiting cash flow, among others. KanBan Implementation are "self-evident signals boards" that indicate what work is to be done and when.

All lean tools defined above should consider in the chemical companies in Ethiopia to control the different wastes of the industries occur due to different factors.

In this study it has been seen that the chemical industry is facing increasing unpredictability and uncertainties. It is subjected to pressures from both upstream and downstream. Raw materials for the industry, such as crude oil and natural gas, plastic and rubbers, have been reporting historic highs. At the same time, the industry is losing its influence on pricing on own products due to the changing value chain. This change is closely related to restructuring of the chemical industry. Chemical firms take every possible measure, regardless of external or internal change, to strengthen their competitive advantage. Many financial and managerial events that have been seen undergo such as core focusing, strategic alliances, spinning off certain businesses are merely consequences of the firms efforts and endeavors to increase competitive advantage in time of rising uncertainties and unpredictability of the chemical business.

Therefore the chemical industries development scenario in Ethiopia should consider the above mentioned lean tools in line with its expansion or establishment of new industries even though few exists as small, medium and large industries and unable to implement lean in their process and operation due to the constraints mentioned in this study.

\section{Conclusions}

The study focused on the global competitiveness in line with lean principles and philosophy in the chemical manufacturing industries. Global competitive has not been achieved without consideration of the fast responsiveness, cost reduction/inventory management and differentiation. In achieving global competitiveness of chemical industries, there are tools those increase the manufacturing industry minimizing the overall wastes as the study showed. To be competitive in the manufacturing industries operation, one of the tools that support waste minimization is lean philosophy. It has been found in literature that it focuses on the elimination of waste through value stream 
Citation: Jilcha K, Kitaw D (2015) Lean Philosophy for Global Competitiveness in Ethiopia Chemical Industries: Review. J Comput Sci Syst Biol 8: 304-321. doi:10.4172/jcsb.1000205

mapping. It cuts off the non-value adding especially unnecessary $35 \%$ operations and minimizes necessary non-value adding activities. But it has been found that there are challenges of implementation of the lean philosophy in manufacturing. However, one of lean tools, JIT (Just-inTime) is a philosophy of manufacturing based on planned elimination of waste and on continuous improvement of productivity. The primary elements of just-in-time are to have only the required inventory when needed; to improve quality to zero defects; to reduce lead times by reducing setup times, queue lengths and lot sizes; to incrementally revise the operations themselves; and to accomplish these activities at minimum cost. Lean is green. Its purpose is to reduce use of resources, to reduce waste, to reduce space and handling (energy) and to increase output per unit of resource used. Further, it can be easily extended to nonproduction areas. Lean recognizes that there is no positive side to waste and that reducing energy usage and emissions can have a positive impact on cash flow.

Global competitiveness in chemical industries is very important initiatives when lean tools are properly utilized. The lean thinking in chemical industries are not yet diffused due to many reasons identified in the literature. Ethiopia has no satisfactory industries to push through and say use lean philosophy. However, it is very important to note that the chemical industries development is initiated by the government and it lets allow them to practice lean just in time of establishment. The chemical manufacturing performance indicators parameter exercised weakness are an indication of non-existing of lean philosophy. As a result of this the competitiveness of Ethiopian chemical manufacturing industries are very weak and almost null. As in the Ethiopia plastic industry case also illustrated that with process problems in production and absent of JIT, on time delivery, value mapping stream processing, and the other lean tools are burden the company to cost more scrap cost and time waste costs. The lean tools absenteeism in chemical industry resulted in more reworks, inventory, large lead time, customer dissatisfaction, loss of productivity and stepping down in general. As a result of this, the GDP contribution of the chemical industry has been found that almost null.

\section{References}

1. Ahmad S, Schroeder RG (2002) Dimensions Of Competitive Priorities: Are They Clear, Communicated, And Consistent? The Journal of Applied Business Research 18: 77-86

2. Deif AM, EIMaraghy $\mathrm{H}$ (2014) Cost performance dynamics in lean production leveling. J Manuf Syst 33: 613-623.

3. Singh B, Garg SK, Sharma SK, Grewal C (2010) Lean implementation and its benefits to production industry. International Journal of Lean Six Sigma 1: 157-168.

4. Rineheart J, Huxley C, Robertson D (1997) Just another Car Factory? Lean Production and its Contents. Cornell University Press, USA

5. Dankbaar B (1997) Lean production: denial, confirmation or extension of sociotechnical systems design? Human Relations 50: 567-584.

6. Papadopoulu TC, Ozbayrak M (2005) Leanness: experiences from the journey to date. Journal of Manufacturing Technology Management 16: 784-807.

7. Gupta S, Jain SK (2013) A literature review of lean manufacturing. International Journal of Management Science and Engineering Management 8: 241-249.

8. Ohno T (1988) Toyota production system: beyond large-scale production Productivity Press, USA.

9. Salah AM Elmoselhy (2013). Hybrid lean-agile manufacturing system technical facet, in automotive sector. J Manuf Syst 8: 153-171.

10. Auston Marmaduke Kilpatrick (1997) Lean Manufacturing Principles: A Comprehensive Framework for Improving Production Efficiency. University of California, Los Angeles, Massachusetts Institute of Technology, USA.
11. Adam Russell (2012) Go Lean It's time for the chemical industry to embrace this production strategy. Eastman Chemical Co.

12. Porter M (1980) Competitive strategy: Techniques for analyzing industries and competitors. London: The Free Press, USA.

13. Melton (2005) The Benefits of Lean Manufacturing, What Lean Thinking has to Offer the Process Industries. Chemical Engineering Research and Design 83: 662-673.

14. Womack JP, Jones DT, Roos D (1990) The Machine that Changed the World: The Story of Lean Production. Harper Collins Publishers, New York, USA

15. Bergmiller G, McWright P (2009) Lean Manufacturers' Transcendence to Green Manufacturing. Proceedings of the Industrial Engineering Research Conference May-June, Miami, FL.

16. Womack JP, Jones DT (1996) Lean Thinking: Banish Waste and Create Wealth in Your Corporation. Simon \& Schuster, New York, USA

17. Standard C, Davis D (2000) Lean thinking for competitive advantage. Automotive Manufacturing and Production 12: 1-3.

18. Asrat Mekonnen (2011) Uses And Applications of Quality Engineering, A case of Ethiopia Plastic Share Company, Master's Thesis, Addis Ababa Institute of Technology, Ethiopia.

19. Powell TC (1995) Total quality management as competitive advantage: A review and empirical study. Strategy Management Journal 16: 15-37.

20. Sanjay Bhasin, Peter Burcher (2005) Lean viewed as a philosophy. Journal of Manufacturing Technology Management 17: 56-72.

21. Dimancescu D, Hines P, Rich N (1997) The Lean Enterprise, Amazon, New York, USA.

22. Maskell B (2000) Lean accounting for lean manufacturers. Manufacturing Engineering, December, 2-5.

23. Meier D (2001) Learning to think lean. Automotive Manufacturing and Production 113: 1-3

24. Kirkor Bozdogan (2010) Towards An Integration Of The Lean Enterprise System, Total Quality Management, Six Sigma And Related Enterprise Process Improvement Methods, Massachusetts Institute of Technology, Cambridge, MA, USA.

25. Zoe Radnor (2000) Changing to a lean organization: the case of a chemicals company. International Journal of Manufacturing Technology and Management 1: 444-453.

26. The Lean and Chemicals Tool kit, Ross \&Associates Environmental Consulting Ltd (2009) In association with Industrial Economics, Inc., United States Environmental Protection Agency.

27. Taher Tourki (2010) Implementation of Lean within the Cement Industry. A thesis submitted in partial fulfillment of the requirement for the Degree of Doctor of Philosophy, De Montfort University, UK.

28. Flynn BB, Sakakibara S, Schroeder RG (1995) Relationship between JIT and TQM: practices and performance. Academy of Management Journal 38: 1325 1360.

29. Global Chemicals Outlook/GCO (2012) Towards Sound Management of Chemicals. United Nations Environment Programme.

30. Mol. Chemical Industry Development Institute Document.

31. Yasuhiko Kamakura (2006) Corporate structural change and social dialogue in the chemical industry, Working papers are preliminary documents circulated to stimulate discussion and obtain comments. International Labor Office, Geneva.

32. http://essentialchemicalindustry.org/the-chemical-industry/the-chemicalindustry.html

33. http://www.cefic.org/Documents/FactsAndFigures/2012/Facts-and-Figures2012-The-Brochure.pdf

34. http://www2.deloitte com/content/dam/Deloitte/global/Documents/ Manufacturing/gx_2010\% $20 \mathrm{Global} \% 20$ Manufacturing $\% 20$ Competitiveness\%20Index_06_28_10.pdf

35. http://iss.ecnu.edu.cn/library/gx_2013\%20Global\%20Manufacturing\%20 Competitiveness\%20Index_11_15_12.pdf 
Citation: Jilcha K, Kitaw D (2015) Lean Philosophy for Global Competitiveness in Ethiopia Chemical Industries: Review. J Comput Sci Syst Biol 8: 304-321. doi:10.4172/jcsb. 1000205

36. http://www.ehow.com/list_6852210_types-chemical-companies.html

37. http://www.cefic.org/Documents/FactsAndFigures/(Offline)\%202011/FF2011_ Full\%20Report_Chapter/Cefic_FF\%20Rapport\%202011.pdf

38. http://en.wikipedia.org/wiki/Intermediate_consumption

39. http://en.wikipedia.org/wiki/Petrochemical
40. http://www.csa.gov.et/index.php/industry-quality-report/ppi-quarterlymanufacturing, retrived

41. http://en.wikipedia.org/wiki/Value_added

42. www.ibef.org

43. http://www.tpslean.com/leantools/leantoolsmenu.htm,29/7/2014 